\title{
Near-surface western boundary circulation off Northeast Brazil
}

\author{
Dossa Alina N. 1, ${ }^{*}$, Costa Da Silva Alex ${ }^{1}$, Chaigneau Alexis 2, 3, 4, Eldin Gérard ${ }^{2}$, Araujo Moacyr 1, 5 , \\ Bertrand Arnaud 1,6,7
}

${ }^{1}$ Laboratório de Oceanografia Física Estuarina e Costeira, Depto. Oceanografia, UFPE, Recife-PE, Brazil

2 Laboratoire d'Études en Géophysique et Océanographie Spatiale (LEGOS), Université de Toulouse, CNES, CNRD, IRD, UPS, Toulouse, France

3 Institut de Recherches Halieutiques et Océanologiques du Bénin (IRHOB), Cotonou, Benin

${ }^{4}$ International Chair in Mathematical Physics and Applications (ICMPA-UNESCO Chair), University of Abomey-Calavi, Cotonou, Benin

${ }^{5}$ Brazilian Research Network on Global Climate Change, São José dos Campos, SP, Brazil

6 Institut de Recherche pour le Développement (IRD), MARBEC, Univ Montpellier, CNRS, Ifremer, IRD, Sète, France

7 Universidade Federal Rural de Pernambuco, Recife, Brazil

*Corresponding author : Alina N. Dossa, email address : nath2dossa@gmail.com

\begin{abstract}
:
In the tropical Atlantic Ocean, the North Brazil Undercurrent (NBUC) and the North Brazil Current (NBC) play important roles as near-surface northward paths for the Atlantic meridional overturning circulation. To investigate the meridional evolution of the near-surface western boundary circulation in that region, two surveys were carried out off Northeast Brazil during austral spring 2015 and fall 2017, periods that we show to be representative of typical conditions for the spring and fall seasons. Using conductivity temperature depth oxygen probe and ship-mounted acoustic Doppler current profiler measurements, altimetry data, and numerical reanalysis products, we examine the spatiotemporal variability of the NBUC, providing a comprehensive view of the circulation, including NBUC-NBC transition and the potential impact of mesoscale eddies. The NBUC originating south of $10^{\circ} \mathrm{S}$ flows equatorward over the continental slope. NBUC mean velocity, transport and vertical extent of the velocity core were higher in spring 2015 $(0.81 \mathrm{~m} \mathrm{~s}-1,15.6 \mathrm{~Sv}$, and $>400 \mathrm{~m})$ than in fall $2017(0.65 \mathrm{~m} \mathrm{~s}-1,11.0 \mathrm{~Sv}$, and $\sim 300 \mathrm{~m})$. The upper limit of the NBUC velocity core rose slightly from $160 \mathrm{~m}$ at $9^{\circ} \mathrm{S}$ to $105 \mathrm{~m}$ depth at $6^{\circ} \mathrm{S}$. This pattern is associated with a northward increase in current velocity from $0.7 \mathrm{~m} \mathrm{~s}^{-1}$ at $9^{\circ} \mathrm{S}$ to $1 \mathrm{~m} \mathrm{~s}^{-1}$ at $5^{\circ} \mathrm{S}$. The orographic effect shifts the flow from northeastward south of $7.5^{\circ} \mathrm{S}$ to northwestward north of $7.5^{\circ} \mathrm{S}$, following the shoreline. Besides, altimetry data show that this flow can be locally influenced by mesoscale activity. Farther north, at $\sim 4.8^{\circ} \mathrm{S}$, data obtained in fall 2017 show that the central branch of the South Equatorial Current (cSEC) enters into the western boundary system where it coalesces with the NBUC to form the NBC, flowing toward the Caribbean Sea. Finally, the NBUC retroflection does not feed the South Equatorial Undercurrent (SEUC), which, instead originates from retroflections of the cSEC and the equatorial branch of the South Equatorial Current (eSEC).
\end{abstract}




\section{Highlights}

- North Brazil Undercurrent (NBUC) and Current (NBC) are important AMOC pathway. Using ADCP we finely describe the NBUC-NBC characteristics at two seasons. We propose a comprehensive picture of NBUC-NBC spatia I patterns and transition. We show how mesoscale activity can impact the surface nearshore circulation.

Keywords : Western Tropical Atlantic, North Brazil Undercurrent, North Brazil Current, Flow-topography interaction, Mesoscale activity, ADCP 
1. Introduction The western tropical Atlantic Ocean is a critical region for the interhemispheric exchange of heat, salt and water mass (Gordon, 1986; Schmitz and McCartney, 1993). In this region, near-surface western boundary currents play major roles in the equatorward patch of the Atlantic Meridional Overturning Circulation (AMOC) (Garzoli, 2004; Schott et al., 2002; Zhang et al., 2011). In particular, the North Brazil Undercurrent (NBUC) and the North Brazil Current (NBC) act as an AMOC channel for the mean northward return flow (Rühs et al., 2015). The NBUC originates from the bifurcation of the southern South Equatorial Current (sSEC) (Figure 1) and controls the northward transport along the eastern portion of the Northeastern Brazilian coast (Peterson and Stramma, 1991; Stramma and Schott, 1999; Lumpkin and Garzoli, 2005; Rodrigues et al., 2007; Silva et al., 2009). The sSEC arises from the westward deflection of the Benguela Current in the southeast Atlantic. During its journey, the sSEC progressively warms and thus carries relatively warm and salty water from the southeast and central South Atlantic northwestward. The sSEC reaches the Brazilian coast at approximately $10-20^{\circ} \mathrm{S}$, where it bifurcates into two branches (Stramma and England, 1999; Rodrigues et al., 2007; Silva et al., 2009; Soutelino et al., 2011). A small part of the sSEC feeds the surface Brazil Current $(\mathrm{BC})$ that flows southward along the Brazilian continental shelf, whereas the main part of the sSEC feeds the subsurface NBUC flowing northward (da Silveira et al., 1994; Stramma et al., 1995; Schott et al., 2005). Although the sSEC is a nearly westward surface current flowing in the first hundreds of meters of the ocean, the NBUC has a weak surface expression and flows predominantly in the subsurface due to the southward wind-driven surface drift in the region (Stramma et al., 1995). Between $10^{\circ} \mathrm{S}$ and $5^{\circ} \mathrm{S}$, along the Brazilian coast, the core of the NBUC transports a South Atlantic water mass characterized by a high oxygen content and high salinity (Arhan et al., 1998; Schott et al., 1998). At $\sim 5^{\circ} \mathrm{S}$, the NBUC is reinforced by the central SEC (cSEC) that enters the western boundary system. The equatorward transport is thus increased, and the NBUC forms the NBC in the near-surface layer.

The above-described large-scale picture of the nearshore circulation off Northeast Brazil (NEB) has mostly been derived from geostrophic and hydrographic data (da Silveira et al., 1994; Schott et al., 1995; Stramma et al., 1995), which do not have the resolution and precision of shipboard acoustic Doppler current profiler (SADCP) data. Some studies, have used SADCP data to investigate the regional circulation (Stramma et al., 1995; Schott et al., 1995, 2003; Bourlès et al., 2002; Goes et al., 2005; Neto and Da Silva, 2014), but they were mostly limited to sections at $5^{\circ} \mathrm{S}$ and $11^{\circ} \mathrm{S}$ and did not provide comprehensive coverage of the NEB region. The general patterns of the NBUC/NBC transition, for example, have been previously examined (da Silveira et al., 1994; Stramma et al., 1995; Bourlès et al., 1999; Schott et al., 2003), but a more detailed description of the connection between these western boundary currents is still needed. Indeed, Bourlès et al. (1999) showed along of the $44^{\circ} \mathrm{W}$ section that in the region where the NBC forms, the NBUC weakens and retroflects to feed the eastward South Equatorial Undercurrent (SEUC). Conversely, Schott et al. (1998) suggested that the SEUC is not fed by the NBUC but rather by the large-scale recirculation of the tropical gyre (the equatorial branch of the south equatorial current, eSEC). Furthermore, Goes et al. (2005) found that apart from the gyre recirculation, there is a minor contribution from the NBUC to the SEUC. This still controversial debate will be investigated in the present study.

In addition to the need to understand the processes in this transition zone, the potential impact of mesoscale eddies on the NBUC/NBC system is not yet documented. Although mesoscale eddies are known to impact ocean boundary flows (Chelton et al., 2007, 2011; McWilliams, 2008), as far as we know this has not been previously investigated along the eastern NEB.

In this context, the objective of this work is to fill gaps on existing knowledge to provide a more comprehensive and updated description of near-surface western boundary circulation 
off Northeast Brazil (Figure 1). All previous NBUC/NBC observing works come from crossshelf transects and mooring array measurements at $5^{\circ} \mathrm{S}$ and $11^{\circ} \mathrm{S}$ (Veleda et al., 2011, 2012; Hummels et al., 2015; Herrford et al., 2020). We aim at describing the spatial variability of the NBUC/NBC system along Northeast Brazil for two different periods of the year. To achieve this goal and to construct a comprehensive picture, two surveys were carried out along the NEB shoreline in austral spring 2015 and fall 2017 (Bertrand, 2015, 2017), when systematic crossshore sections of conductivity-temperature-depth-oxygen (CTDO) were obtained and underway SADCP measurements were performed. Using such a dataset and altimetry information, we examined the spatial variability of the NBUC/NBC system during both periods. Although synoptic, those measurements appear to be representative of spring and fall canonical conditions and allow a detailed analysis of the equatorward evolution of the NBUC, its interaction with shelf topography, and its transition from under to surface current (NBUC/NBC). Finally, we show how mesoscale activity can impact the near-surface circulation.

\section{Material and methods}

\subsection{In situ measurements}

Data were collected during two multidisciplinary 'Acoustic along the Brazilian Coast' (ABRAÇOS) surveys performed along the continental slope of the NEB (Figure 2) onboard the R/V Antea in austral spring 2015 (September 28 - October 21, 2015) and fall 2017 (April 9 May 8, 2017) (Bertrand, 2015; 2017). The survey pattern consisted of systematic cross-shore sections (Figure 2). An 'Ocean Surveyor' ship-mounted acoustic Doppler current profiler (SADCP) operating at a frequency of $75 \mathrm{kHz}$ with a depth range of $15-700 \mathrm{~m}$ was used to measure the zonal and meridional components of the currents in the upper water column. Raw SADCP data were acquired every $3 \mathrm{~s}$ in deep water $(>150 \mathrm{~m}$ bottom depth) and every $1 \mathrm{~s}$ in shallow water ( $<150 \mathrm{~m}$ bottom depth) using a vertical bin length of $8 \mathrm{~m}$. Velocities estimated from each ping were vector-averaged in each vertical bin into 10 min ensembles.

SADCP data were processed and edited using the Common Ocean Data Access System (CODAS) software package developed at the University of Hawaii ( http://currents.soest.hawaii.edu). The relative velocities were rotated from the transducer to the Earth reference frame using the ship gyrocompass. The global positioning system (GPS) was used to retrieve the absolute current velocities. The orientation of the transducer relative to the gyroscopic compass and an amplitude correction factor for the ADCP were determined by standard calibration procedures (Joyce, 1989; Pollard and Read, 1989). Finally, velocity profiles were averaged hourly, providing profiles in the 19-600 $\mathrm{m}$ depth range. SADCP data located over the shelf (bathymetry shallower than $70 \mathrm{~m}$ ) were often affected by spurious reflections on the bottom, so the data coverage was only partial in these shallow areas.

To describe the main currents, we divided the data into two layers: the upper layer (0$70 \mathrm{~m})$ and the subsurface layer $(70-350 \mathrm{~m})$. These limits of $70 \mathrm{~m}$ and $350 \mathrm{~m}$ depth correspond to the relative depths where $\sigma_{\theta}=24.5 \mathrm{~kg} \mathrm{~m}^{-3}$ and $\sigma_{\theta}=26.8 \mathrm{~kg} \mathrm{~m}^{-3}$, respectively. These isopycnals were defined in previous studies on the basis of the current distribution associated with the density structures (Bourles et al., 2002; Goes et al., 2005; Schott et al., 2005). Indeed, these isopycnals also correspond to the limits of the current and water mass cores of the region. The NBC core is located above $\sigma_{\theta}=24.5 \mathrm{~kg} \mathrm{~m}^{-3}$, while the NBUC core and the thermocline are located between $\sigma_{\theta}=24.5 \mathrm{~kg} \mathrm{~m}^{-3}$ and $26.8 \mathrm{~kg} \mathrm{~m}^{-3}$ (Bourlès et al., 1999a; Goes et al., 2005). Note that for the mean circulation in the upper layer $(0-19 \mathrm{~m})$, the current velocity was set equal to the first level of the ADCP data (i.e., $19 \mathrm{~m}$ ) because the mixed-layer depth is deeper than 19 $\mathrm{m}$ throughout the region (Araujo et al., 2011; Assunção et al., 2020). This step may induce a 
slight bias due to the Ekman ageostrophic circulation, which is maximum at the sea surface and decreases with depth.

We estimated alongshore velocities between the shelf break (isobath $70 \mathrm{~m}$ ) and $60 \mathrm{~km}$ offshore (or to the transect limit when shorter than $60 \mathrm{~km}$ from the shelf break). To represent the average velocities between $9^{\circ} \mathrm{S}$ and $6^{\circ} \mathrm{S}$, we horizontally interpolated SADCP velocity data into $5 \mathrm{~km}$ bins from the shelf break to the outermost limit of each cross-shore transect. To better depict the latitudinal variations, we interpolated alongshore and cross-shore velocity data by latitude bins of $1^{\circ}$. We defined the NBUC core as the area where the alongshore velocities were greater than $70 \%$ of its maximum. This criterion, chosen after sensitivity tests permits to capture the core of the NBUC in the subsurface layer, as observed in previous studies where the NBUC core was centred at 150-300 m (e.g., Bourlès et al. 1999b; Veleda et al., 2011, 2012; Hummels et al., 2015; Herrford et al., 2020).

Mean transports (in Sv) and the associated standard deviations around the mean were calculated within the two layers described above $(0-70 \mathrm{~m}$ and $70-350 \mathrm{~m})$ and also in the range $0-500 \mathrm{~m}$. Alongshore transports between $9.4^{\circ} \mathrm{S}$ and $5^{\circ} \mathrm{S}$ were computed between the shelf break and $20 \mathrm{~km}$ offshore (i.e., the offshore extent of the shortest transect).

Vertical profiles of physical and biogeochemical parameters were collected from the surface to $1000 \mathrm{~m}$ depth using a Seabird SBE911+ conductivity temperature depth (CTD) probe equipped with a dissolved oxygen sensor (CTDO). The temperature and conductivity sensors were laboratory-calibrated before and after each cruise. In total, 47 and 49 profiles were acquired during the cruises performed in austral spring 2015 and austral fall 2017, respectively. Conductivity, temperature and pressure accuracies were estimated to be $3 \mathrm{mS} \mathrm{m}^{-1}, 10^{-3 \circ} \mathrm{C}$ and $0.7 \mathrm{dbar}$, respectively. Here, we considered only the profiles obtained off the shelf break (Figure 2). Following previous studies (Schott et al., 1995; Goes et al., 2005; Urbano et al., 2008), we selected data at distinct locations as reference sources for South Atlantic water (SAW) for austral spring and austral fall. The data sources used as reference sources for the SAW were acquired from the ETAMBOT cruise (Gouriou, 1995) at $4^{\circ} \mathrm{S}, 35^{\circ} \mathrm{W}$ (September 1995, austral spring) and from the World Ocean Atlas data set (http:// www.nodc.noaa.gov/OC5/WOD) at $16^{\circ} \mathrm{S}, 24^{\circ} \mathrm{W}$ (May 1994, austral fall).

\subsection{Altimetry and reanalysis data}

To investigate mesoscale activity in the nearshore NEB region, we analysed satellite altimeter data of sea surface height (SSH) from the Data Unification and Altimeter Combination System (DUACS) multimission product. This dataset spans from January 1993 to the present and is mapped daily onto a $0.25^{\circ} \times 0.25^{\circ}$ latitude/longitude grid (Ablain et al., 2015; Dupuy et al., 2016). This SSH product is based on measurements from several altimeter missions (Jason3, Sentinel-3A, HY-2A, Saral/AltiKa, Cryosat-2, Jason-2, Jason-1, T/P, ENVISAT, GFO, and ERS1/2). The processing and distribution of the product is provided by the Copernicus Marine Environment Monitoring Service (CMEMS: http://marine.copernicus.eu).

SSH and geostrophic current conditions in spring 2015 and fall 2017 were used to identify the possible presence of mesoscale eddies and to investigate their impact on the nearshore circulation.

This dataset was also used to determine whether the conditions observed in spring 2015 and fall 2017 during the ABRAÇOS cruises are representative of the mean states for spring and fall or, in contrast, if these conditions differ from the mean climatological states. For this purpose, we constructed the climatology of SSH and geostrophic currents using data from January 1993 to December 2018 for all four seasons and more specifically for the two climatological periods corresponding to the ABRAÇOS surveys: spring (September $29-$ October 21) and fall (April 8 - May 9). These climatologies were then compared to the SSH and geostrophic current conditions observed during spring 2015 and fall 2017. To facilitate the 
comparison, we also computed a map of SSH and geostrophic current anomalies between the climatology and survey conditions.

In addition, to compare our observations and replace them within a broader seasonal and interannual perspective we used the global ocean reanalysis product GLORYS12V1 that assimilates vertical profile and satellite data. This product is based on the current real-time global forecasting CMEMS system (http://marine.copernicus.eu). The ocean model component is the NEMO platform forced at the surface by ECMWF ERA-Interim reanalysis. Observations are assimilated by means of a reduced-order Kalman filter. This product is distributed on a standard regular grid at 1/12 degree and on 50 standard levels and consists on daily fields from 1993 to 2018.

\section{Results}

\subsection{Water masses}

TS diagrams and oxygen-salinity curves confirmed the dominance of South Atlantic water masses in the NEB region (Figure 3 ). Four water masses could be identified. In the surface layer $(\sim 0-100 \mathrm{~m})$, lays the Tropical Atlantic water (TW) characterised by temperature $>25^{\circ} \mathrm{C}$ and isopycnals $\sigma_{\theta}$ between 23 and $24.5 \mathrm{~kg} \mathrm{~m}^{-3}$. Below, between $\sim 80-150 \mathrm{~m}$ lays the Subtropical Underwater (SUW), characterized by maximum salinity (core salinity $>36.5$ ) and densities slightly below $\sigma_{\theta} 25 \mathrm{~kg} \mathrm{~m}^{-3}$. Then, down to $500 \mathrm{~m}$, lays the South Atlantic central water (SACW) characterised by temperatures ranging from $10^{\circ} \mathrm{C}$ to $23^{\circ} \mathrm{C}$ and salinities $>35\left(24.5<\sigma_{\theta}<27 \mathrm{~kg} \mathrm{~m}^{-}\right.$ ${ }^{3}$, Stramma and England, 1999). Finally, at greater depths, with $\sigma_{\theta}>27 \mathrm{~kg} \mathrm{~m}^{-3}$, we observed the presence of Antarctic intermediate water (AAIW) characterized by low salinity (da Silveira et al., 1994; Stramma and England, 1999).

In the TW level, the temperature was $\sim 2^{\circ} \mathrm{C}$ warmer in fall 2017 than spring 2015 (Figure $3 a, b)$. The vertical extent of the maximal salinity core (SUW) was however greater in fall, especially towards the surface. This was consistent with the trend observed for the mixed layer depth and the upper thermocline and halocline depths that were shallower in fall than in spring (Figure 3; Assunção et al., 2020). The dissolved oxygen concentration was overall higher than $140 \mu \mathrm{mol} \mathrm{l}^{-1}$ along the water column except for two profiles in fall 2017, where a clear oxycline occurred with the dissolved oxygen concentration decreasing to $100 \mu \mathrm{mol} \mathrm{l}^{-1}$ in the depth range $\sim 150-400 \mathrm{~m}$. These two profiles were located north of $4^{\circ} \mathrm{S}$ at $35^{\circ} \mathrm{W}$ and $34.5^{\circ} \mathrm{W}$, where Eastern Atlantic Water, characterized by a low oxygen content, is transported by the equatorial branches of the south equatorial current (eSEC and cSEC).

\subsection{Meridional variability of the NBUC/NBC currents and transport}

In spring 2015 and fall 2017, the circulation along the northeastern Brazilian coast was predominantly equatorward between $9.4^{\circ} \mathrm{S}$ and $4.2^{\circ} \mathrm{S}$, both in the upper $(0-70 \mathrm{~m})$ and subsurface $(70-350 \mathrm{~m})$ layers (Figure 4). However, in spring 2015, the upper layer equatorward flow weakened between $7.8^{\circ} \mathrm{S}$ and $8.3^{\circ} \mathrm{S}$ with even a southward flow occurring $\left(\sim-0.1 \mathrm{~m} \mathrm{~s}^{-1}\right)$. This pattern was also evidenced by the upper alongshore velocity that almost vanished at approximately $8.2^{\circ} \mathrm{S}$ (Figure $4 \mathrm{c}$, blue line). This weakening was further observed in the subsurface circulation (Figure 4b, c), although to a lesser extent. Overall, the subsurface flow was consistently equatorward, which is characteristic of the NBUC, with an intensification between $8^{\circ} \mathrm{S}$ and $7^{\circ} \mathrm{S}$ (mean velocity reaching $1 \mathrm{~m} \mathrm{~s}^{-1}$ ).

Contrary to spring 2015, during fall 2017, we did not observe any clear signal of weakening of the upper layer equatorward flow at $\sim 8^{\circ} \mathrm{S}$ but a small flow reduction near $8.5^{\circ} \mathrm{S}$ (Figure $4 \mathrm{~d}, \mathrm{e}, \mathrm{f}$ ). Both surface and subsurface flows increased between $8^{\circ} \mathrm{S}$ and $7^{\circ} \mathrm{S}$ and at $\sim 5.5^{\circ} \mathrm{S}$, with the mean velocities reaching $0.7 \mathrm{~m} \mathrm{~s}^{-1}$ and $\sim 1 \mathrm{~m} \mathrm{~s}^{-1}$ in the upper and subsurface layers, respectively. In fall 2017 , north of $5^{\circ} \mathrm{S}$ (no data were acquired north of $5^{\circ} \mathrm{S}$ in spring 
2015), where the coastal orientation changes, the circulation was consistently northwestward in both layers but was comparatively weaker in the subsurface layer, especially at $4.2-5^{\circ} \mathrm{S}, 36$ $35.5^{\circ} \mathrm{W}$. North of $4^{\circ} \mathrm{S}$, the upper layer flow was greater than the subsurface flow between $35.5^{\circ} \mathrm{W}$ and $34.5^{\circ} \mathrm{W}$. The $3 \mathrm{D}$ representations of the flow over the continental slope (Figure 5) provide a more comprehensive view of the current dynamics (see Figure S1 for 2D corresponding 2D section). During both seasons, the zonal flow was mainly eastward between $9^{\circ} \mathrm{S}$ and $7.5^{\circ} \mathrm{S}$, with velocities up to $0.3 \mathrm{~m} \mathrm{~s}^{-1}$. North of $7.5^{\circ} \mathrm{S}$, this flow suddenly shifted westward with velocities reaching $0.3 \mathrm{~m} \mathrm{~s}^{-1}$. In fall 2017, north of $5.7^{\circ} \mathrm{S}$ (no data for spring 2015), the westward strength of the zonal flow (Figure 5b) increased in the upper layer. However, the zonal flow was eastward in the subsurface layer over the region $5-4.8^{\circ} \mathrm{S}, 36$ $35.5^{\circ} \mathrm{W}$. The meridional flow (Figure $5 \mathrm{c}, \mathrm{d}$ ) was dominantly equatorward along the coast at approximately $100-500 \mathrm{~m}$ depth with a clear intensification north of $8^{\circ} \mathrm{S}$ in spring 2015 and north of $6^{\circ} \mathrm{S}$ in fall 2017 . In fall 2017 , nevertheless, the flow strength decreased between $36^{\circ} \mathrm{W}$ and $35.5^{\circ} \mathrm{W}$.

The alongshore velocity averaged between $9^{\circ} \mathrm{S}$ and $6^{\circ} \mathrm{S}$ revealed dominance of the NBUC with strong positive equatorward flow during both seasons (Figure 6). In spring 2015, the core of the NBUC (area where the alongshore velocity is greater than $70 \%$ of its maximum) extended from $105 \mathrm{~m}$ to more than $500 \mathrm{~m}$ depth and between 2 and $40 \mathrm{~km}$ from the shelf break, with velocities reaching $0.9 \mathrm{~m} \mathrm{~s}^{-1}$ (mean: $0.81 \mathrm{~m} \mathrm{~s}^{-1}$ ) Figure $6 \mathrm{a}$ ). At depths less than $\sim 100 \mathrm{~m}$, the equatorward flow strongly weakened. The average total transport integrated between the shelf break and $40 \mathrm{~km}$ offshore and between the surface and $500 \mathrm{~m}$ depth was $15.6 \pm 4.3 \mathrm{~Sv}$ (Figure 6b). The alongshore transport integrated between the shelf break and $40 \mathrm{~km}$ offshore was maximum $\left(>\sim 0.04 \mathrm{~Sv} \mathrm{~m}{ }^{-1}\right.$ ) between $135 \mathrm{~m}$ and $450 \mathrm{~m}$ depth (Figure 6b), which corresponded to the NBUC core. Horizontally, the vertically integrated transport between the surface and $500 \mathrm{~m}$ depth was maximum $\left(>0.8 \mathrm{~km}^{-1}\right)$ between 5 and $25 \mathrm{~km}$ from the shelf break (Figure 6c). In fall 2017 (Figure 6d, e, f), the NBUC velocity core was less intense and shallower but extended farther offshore than in spring 2015 . Its velocity core ranged between $\sim 80 \mathrm{~m}$ and $390 \mathrm{~m}$ depth and extended between $3 \mathrm{~km}$ and more than $40 \mathrm{~km}$ from the shelf break, with velocities reaching $0.7 \mathrm{~m} \mathrm{~s}^{-1}$ (mean: $0.65 \mathrm{~m} \mathrm{~s}^{-1}$ ) (Figure 6d). Surface velocities were higher than in spring 2015 (Figure 6d), as also seen in Figure 5. With $11.0 \pm 2.6 \mathrm{~Sv}$, the average total transport integrated between the shelf break and $40 \mathrm{~km}$ offshore and between the surface and $500 \mathrm{~m}$ depth was $\sim 4.6 \mathrm{~Sv}$ weaker than in spring 2015. The mean alongshore transport integrated between the shelf break and $40 \mathrm{~km}$ offshore was maximum $\left(>\sim 0.03 \times 10^{-1} \mathrm{~Sv} \mathrm{~m}^{-1}\right)$ between 100 and $330 \mathrm{~m}$ depth (Figure 6e), which corresponded to the centre of the NBUC core. Horizontally, the integrated transport between the surface $\mathrm{m}$ and $500 \mathrm{~m}$ depth was maximum $\left(>\sim 0.6 \mathrm{~Sv} \mathrm{~km}{ }^{-1}\right.$ ) between 5 and $30 \mathrm{~km}$ from the shelf break (Figure 6f), similar to what was observed in spring 2015.

To better describe the meridional variation of the nearshore circulation and transport in the NEB region, we averaged the cross-shore sections by latitude bands of $1^{\circ}$ between $9^{\circ} \mathrm{S}$ and $5^{\circ} \mathrm{S}$ (Figure 7; Table 1).

In spring 2015 (Figure 7a), between $9^{\circ} \mathrm{S}$ and $8^{\circ} \mathrm{S}$, the NBUC velocity core was located between $160 \mathrm{~m}$ and $550 \mathrm{~m}$ depth and extended between the shelf break and $40 \mathrm{~km}$ offshore, with velocities up to $0.8 \mathrm{~m} \mathrm{~s}^{-1}$. Above $100 \mathrm{~m}$ depth, the alongshore velocity was very weak with velocity values of less than $0.2 \mathrm{~m} \mathrm{~s}^{-1}$. Between $8^{\circ} \mathrm{S}$ and $7^{\circ} \mathrm{S}$, the cross-shore sections were shorter, hampering a robust estimate of the extent of the NBUC. The NBUC velocity core extended from $\sim 120 \mathrm{~m}$ to more than $600 \mathrm{~m}$ depth and extended from the shelf break to the length of the cross-shore section $(20 \mathrm{~km})$. The velocity was higher than that farther south, reaching values up to $1.2 \mathrm{~m} \mathrm{~s}^{-1}$ (Figure 7a). Between $7^{\circ} \mathrm{S}$ and $6^{\circ} \mathrm{S}$, the NBUC velocity core extended from $105 \mathrm{~m}$ to $\sim 600 \mathrm{~m}$ depth and from $\sim 5 \mathrm{~km}$ from the shelf break to the length of the section $\left(30 \mathrm{~km}\right.$ ). Velocities were lower (up to $0.9 \mathrm{~m} \mathrm{~s}^{-1}$ ) than those observed between $8^{\circ} \mathrm{S}$ and 
$7^{\circ} \mathrm{S}$. Overall, in spring 2015, the NBUC velocity core increased from $0.8 \mathrm{~m} \mathrm{~s}^{-1}$ at $9^{\circ} \mathrm{S}$ to $1.2 \mathrm{~m}$ $\mathrm{s}^{-1}$ at $7^{\circ} \mathrm{S}$ and then decreased to $0.9 \mathrm{~m} \mathrm{~s}^{-1}$, and its upper limit shallowed from $160 \mathrm{~m}$ at $9^{\circ} \mathrm{S}$ to $105 \mathrm{~m}$ at $6^{\circ} \mathrm{S}$ due to the strong vertical shear.

In fall 2017 (Figure $7 \mathrm{~b}$ ), between $9^{\circ} \mathrm{S}$ and $8^{\circ} \mathrm{S}$, the NBUC velocity core was centred at $70-440 \mathrm{~m}$ depth and extended between the shelf break and $30 \mathrm{~km}$ offshore with velocity up to $0.7 \mathrm{~m} \mathrm{~s}^{-1}$. Above $100 \mathrm{~m}$ depth, consistent velocity values $\left(>0.3 \mathrm{~m} \mathrm{~s}^{-1}\right)$ were observed. As in spring 2015, the NBUC velocity intensified north of $8^{\circ} \mathrm{S}$. From $8^{\circ} \mathrm{S}$ to $5^{\circ} \mathrm{S}$, the velocity core was rather consistent with the velocity reaching $1 \mathrm{~m} \mathrm{~s}^{-1}$ at $5^{\circ} \mathrm{S}$. However, its vertical range and width varied according to the latitude bands. Between $8^{\circ} \mathrm{S}$ and $7^{\circ} \mathrm{S}$, it was vertically extended to $50-350 \mathrm{~m}$ depth and located between the shelf break and $\sim 40 \mathrm{~km}$ offshore, with velocity up to $0.9 \mathrm{~m} \mathrm{~s}^{-1}$. In the latitude band $7-6^{\circ} \mathrm{S}$, the NBUC velocity core extended vertically from $80-$ $380 \mathrm{~m}$ depth and horizontally between $\sim 5$ and $50 \mathrm{~km}$ from the shelf break, with velocity reaching $0.8 \mathrm{~m} \mathrm{~s}^{-1}$. Between $6^{\circ} \mathrm{S}$ and $5^{\circ} \mathrm{S}$, the NBUC velocity core was located at $50-340 \mathrm{~m}$ depth and $\sim 5$ and $50 \mathrm{~km}$ from the shelf break. Overall, in fall 2017, the NBUC velocity core increased from $0.7 \mathrm{~m} \mathrm{~s}^{-1}$ at $9^{\circ} \mathrm{S}$ to $1 \mathrm{~m} \mathrm{~s}^{-1}$ at $5^{\circ} \mathrm{S}$, and its core shallowed from $70-440 \mathrm{~m}$ depth at $9^{\circ} \mathrm{S}$ to $50-350 \mathrm{~m}$ depth at $5^{\circ} \mathrm{S}$. Note that in both spring 2015 and fall 2017 , strong velocity shears were observed in the upper layer between the surface and $100 \mathrm{~m}$ depth or at the base of the NBUC core. These vertically sheared currents, characterized by vertical velocity gradients of $6.10^{-3} \mathrm{~m} \mathrm{~s}^{-1}$ per $\mathrm{m}$, might be baroclinically unstable, providing a mechanism of formation for mesoscale eddies (Bourlès et al. 1999b).

To estimate the whole transport of the NBUC, we also calculated the alongshore transport integrated between the shelf break and $20 \mathrm{~km}$ between 0 and $500 \mathrm{~m}$ (Figure 8). In addition, for comparison with earlier studies (Table 1), we estimated the transports between 0 and $70 \mathrm{~m}$, and in the range 70-350 $\mathrm{m}$, corresponding to the isopycnals $\sigma_{\theta}=24.5 \mathrm{~kg} \mathrm{~m}^{-3}$ and $\sigma_{\theta}$ $=26.8 \mathrm{~kg} \mathrm{~m}^{-3}$.

In the upper layer $(0-70 \mathrm{~m})$, the transport was relatively weak $(\sim 0.4-2 \mathrm{~Sv})$ and mainly northward between $9.2^{\circ} \mathrm{S}$ and $6^{\circ} \mathrm{S}$ during both periods (Figure 8). However, the transport was null or slightly southwards at $\sim 8^{\circ} \mathrm{S}$ in spring 2015 (Figure 8). Due to the shallowing of the NBUC, the surface equatorward transport slightly increased northward from $0.7 \mathrm{~Sv}$ at $9^{\circ} \mathrm{S}$ to $1.2 \mathrm{~Sv}$ at $6^{\circ} \mathrm{S}$. Surface transport was slightly stronger in fall 2017 , particularly between $8.5^{\circ} \mathrm{S}$ and $7^{\circ} \mathrm{S}$. In the subsurface layer $(70-350 \mathrm{~m})$, the alongshore transport associated with the equatorward-flowing NBUC varied between 4.5 and $11 \mathrm{~Sv}$ in both periods (Figure 8). The meridional variations were similar in both periods, with an overall increase from south $(6.1 \mathrm{~Sv}$ at $\left.8.5^{\circ} \mathrm{S}\right)$ to the north $\left(9.4 \mathrm{~Sv}\right.$ at $\left.6.2^{\circ} \mathrm{S}\right)$, except at $9.2-8.5^{\circ} \mathrm{S}$ and $7.1-7.6^{\circ} \mathrm{S}$, where the transport was higher in spring 2015 than in fall 2017 ( 2.9 Sv difference).

The total alongshore transport calculated above $500 \mathrm{~m}$ depth varied between $6.2 \mathrm{~Sv}$ and 16.9 Sv in spring 2015 and between 7.2 Sv and 17.2 Sv in fall 2017 (Figure 8). Its meridional variations were similar in both periods. However, it was higher in spring 2015 than in fall 2017 at $9.2^{\circ} \mathrm{S}-8.5^{\circ} \mathrm{S}\left(\sim 5.4 \mathrm{~Sv}\right.$ difference) and at $7.1^{\circ} \mathrm{S}-6.5^{\circ} \mathrm{S}\left(\sim 6.5 \mathrm{~Sv}\right.$ difference). At $\sim 8.1^{\circ} \mathrm{S}$, it weakened $(6.2 \mathrm{~Sv})$ in spring 2015.

\subsection{NBUC/NBC transition}

North of $5^{\circ} \mathrm{S}$, the coastal orientation changes. In this region, the transition between the NBUC and the NBC has been previously reported (e.g., Schott et al., 1998; Bourlès et al., 1999a). To provide a comprehensive view of the current dynamics in this transitional region, we describe the circulation pattern between $5^{\circ} \mathrm{S}$ and $3^{\circ} \mathrm{S}$ during fall 2017 (Figure 9). The longitudinal $\left(36.3^{\circ} \mathrm{W}-34.7^{\circ} \mathrm{W}\right)$ variation of latitudinal transects $\left(4.1^{\circ} \mathrm{S}-3.3^{\circ} \mathrm{S}\right)$ revealed the presence of a variety of features in this transitional area (Figure 9d). Between the surface and $70 \mathrm{~m}$ we observed a consistent westward transport (see Table 1 for transport calculations). This 
transport increased from east to west from $-1.9 \pm 0.1$ at $34.7^{\circ} \mathrm{W}$ to $5.6 \pm 0.1 \mathrm{~Sv}$ at $35.4^{\circ} \mathrm{W}$ and $6.3 \pm 0.1 \mathrm{~Sv}$ at $36^{\circ} \mathrm{W}$ and $36.4^{\circ} \mathrm{W}$ (Table 1). According to previous works (e.g., Stramma et al., 1995; Bourlès et al., 1999b), this flow can be related to the cSEC in the east and to the NBC west of $35.5^{\circ} \mathrm{W}$ with no clear limits (see also the geostrophic currents in Figure 9a). Below, we observed two main patterns. In the eastern transects $\left(34.7^{\circ} \mathrm{W}-36^{\circ} \mathrm{W}\right)$, a southeastward subsurface flow, characteristic of the SEUC, occurred. This southeastward flow observed north of $3.8^{\circ} \mathrm{S}$ had velocities of $\sim 0.1 \mathrm{~m} \mathrm{~s}^{-1}$, a narrow vertical range $\sim 250-350 \mathrm{~m}$ and a transport of 0.2 Sv in western transects. It increased to reach velocity up to $0.3 \mathrm{~m} \mathrm{~s}^{-1}$, a vertical extension ranging from $\sim 150$ to $570 \mathrm{~m}$ and a transport up to $3.4 \mathrm{~Sv}$ in eastern transects $\left(35^{\circ} \mathrm{W}-34.7^{\circ} \mathrm{W}\right)$ (Figure $9 \mathrm{~d}$, Table 1 in bold). South of $3.8^{\circ} \mathrm{S}$, between $36.3^{\circ} \mathrm{W}$ and $35^{\circ} \mathrm{W}$, we observed a consistent northwestward flow over $0-500 \mathrm{~m}$, associated with the NBUC/NBC, with a stronger zonal intensity (at $36.4^{\circ} \mathrm{W}$ the maximum speed and transport were of $1.4 \mathrm{~m} \mathrm{~s}^{-1}$ and $39.5 \pm 3.2 \mathrm{~Sv}$, respectively) (Figure 9d).

Now, we describe the current dynamics latitudinally $\left(5^{\circ} \mathrm{S}-3.2^{\circ} \mathrm{S}\right)$ by two meridional bands (from east to west, Figure $9 \mathrm{~b}$ and Figure 9c, as indicated in Figure 9a by green and red rectangles, respectively). First, in the region $34.7^{\circ} \mathrm{W}-35.4^{\circ} \mathrm{W}$ (green rectangle), we observed a consistent northwestward surface flow, the NBC-cSEC (above $\sim 100 \mathrm{~m}$ ), along $5^{\circ} \mathrm{S}-3.3^{\circ} \mathrm{S}$, with no clear limit between the NBC and the cSEC (Figure, 9a, b). The westward transport estimated between the surface and $70 \mathrm{~m}$ depth was $7.6 \pm 0.8 \mathrm{~Sv}$ i.e., much higher than the transport arriving from the south $(2.1 \mathrm{~Sv}$; Table 1) illustrating the role of the cSEC. Below this depth, the flow was consistently northwestward south of $\sim 3.8^{\circ} \mathrm{S}$ with velocities up to $1 \mathrm{~m} \mathrm{~s}^{-1}$ (characteristic of the NBUC) (Figure 9b). The westward transport crossing the section $35^{\circ} \mathrm{W}$ at $70-350 \mathrm{~m}$ depth was $15.8 \pm 4.6 \mathrm{~Sv}$. Finally, north of $\sim 3.8^{\circ} \mathrm{S}$, the flow was mainly southeastward (characteristic of the SEUC) in the depth range of $\sim 120-330 \mathrm{~m}$, with velocity up to $0.2 \mathrm{~m} \mathrm{~s}^{-1}$ and was associated with eastward transport up to $2.6 \pm 1.2 \mathrm{~Sv}$.

Second, in the region $35.3^{\circ} \mathrm{W}-36^{\circ} \mathrm{W}$ (red rectangle), we observed a surface northwestward flow along $5^{\circ} \mathrm{S}-3.3^{\circ} \mathrm{S}$ with velocity up to $1 \mathrm{~m} \mathrm{~s}^{-1}$ (Figure 9c). The westward transport crossing the section at $35.8^{\circ} \mathrm{W}$, estimated between the surface and $70 \mathrm{~m}$ depth, was $8.7 \pm 1.1 \mathrm{~Sv}$. In the subsurface layer, the patterns varied with latitude. South of $4.8^{\circ} \mathrm{S}$ we observed a northwestward pattern consistent with the NBUC. Between $4.8^{\circ} \mathrm{S}$ and $\sim 4.4^{\circ} \mathrm{S}$, the subsurface flow was mainly positive (eastward) with no clear meridional pattern. We cannot propose a clear diagnosis for this region that is likely affected by complex orographic processes. Between $\sim 4.4^{\circ} \mathrm{S}$ and $3.7^{\circ} \mathrm{S}$, the flow was consistently northwestward over the water column but stronger (characteristic of the NBC) in the surface layer (above $\sim 150 \mathrm{~m}$ ). In the depth range of 70-350 $\mathrm{m}$ depth, the westward transport crossing the section $5^{\circ} \mathrm{S}-3.3^{\circ} \mathrm{S}, 35.3^{\circ} \mathrm{W}-36^{\circ} \mathrm{W}$ increased to 14.2 $\pm 4.2 \mathrm{~Sv}$. Finally, north of $3.7^{\circ} \mathrm{S}$, we observed a northwestward flow above $\sim 150 \mathrm{~m}$, an eastward flow between $\sim 150 \mathrm{~m}$ and $300 \mathrm{~m}$ with $0.6 \mathrm{~Sv}$ as eastward transport, and a weak southwestern flow in the range of $\sim 300-600 \mathrm{~m}$.

\subsection{Mesoscale activity and representativeness of spring 2015 and fall 2017 conditions}

When comparing the SSH and surface geostrophic currents between the seasonal climatologies and the conditions observed during the surveys (Figure 10) in the slope region, we observe similar patterns with, however, some differences. Indeed, the SSH was higher overall during spring 2015 and fall 2017 when compared with climatological conditions. However, although the SSH was higher, geostrophic currents were overall similar in the study area $\left(\sim 0.3-0.4 \mathrm{~m} \mathrm{~s}^{-1}\right)$ when comparing the survey periods to climatological conditions (maximal difference in current velocity $<0.1 \mathrm{~m} \mathrm{~s}^{-1}$ ). Differences in geostrophic currents are notable only in regions where mesoscale eddies occurred during the survey periods. Indeed, mesoscale activity is flattened in climatological pictures but clear when considering the survey periods, which explains these eddy-related differences. 
The nearshore geostrophic circulation was mainly equatorward in the NEB region during spring 2015 (Figure 10). However, as indicated above, we observed an area between $7.8^{\circ} \mathrm{S}$ and $8.3^{\circ} \mathrm{S}$ with weak surface currents and even the occurrence of southward flow (Figure $10 \mathrm{a}, \mathrm{c})$. This area matches the presence of an anticyclonic eddy with a radius of $\sim 50 \mathrm{~km}$ that locally impacted the surface circulation (Figure 10b; Supplementary material Figure S2). The impact of this eddy was, to a lesser extent, also observable in the subsurface (Figure $4 \mathrm{~b}, \mathrm{c}$ ). The coastal eddy observed in our data evolved slightly during the survey period. On October 10, 2015 , it extended longitudinally over $35-34^{\circ} \mathrm{W}$, with its core located at $8.9^{\circ} \mathrm{S}, 34.1^{\circ} \mathrm{W}$. Then, it moved slightly around its origin position and disappeared 10 days later.

In fall 2017, the nearshore geostrophic circulation was also mainly equatorward (Figure 10). Several eddies were detected (Supplementary material Figure S3). For instance, between $6-7^{\circ} \mathrm{S}$ and $34.5-33.5^{\circ} \mathrm{W}$, a cyclonic eddy with a radius of $\sim 55 \mathrm{~km}$ was observed offshore on April 13, 2017, but it disappeared two days later. Another cyclonic eddy was detected offshore in the southern part of the study area $\left(34^{\circ} \mathrm{W}-32^{\circ} \mathrm{W}, 10^{\circ} \mathrm{S}-8^{\circ} \mathrm{S}\right)$. This eddy originated at $33^{\circ} \mathrm{W}$, $8.8^{\circ} \mathrm{S}$ on April 13, 2017, and disappeared on April 30, 2017, with a constant position (Supplementary material Figure S3). This eddy occurred oceanward of the survey area. We could not observe any clear impact of this eddy on the nearshore circulation except in the extreme southern survey area where surface equatorward circulation seemed enhanced (Figures $4,10)$.

Another important question is the extent to which the features we described for spring 2015 and fall 2017 are representative of canonical spring and fall conditions and these conditions ranges within the overall seasonal maximum and minimum.

For this purpose, we considered the use of GLORYS12V1 reanalysis products for the period 1993-2018. The climatological seasonal variability reproduced by GLORYS for the $6^{\circ}$ $9^{\circ} \mathrm{S}$ latitudinal band between the shelf-break and $150 \mathrm{~km}$ offshore is weak (Supplementary material Figure S4). More specifically, if we compare the GLORYS climatologies for the fall and spring seasons with the GLORYS product corresponding to the periods of the two ABRAÇOS surveys (Supplementary material Figure S5) we notice several limitations. First, the position of the NBUC core is shifted offshore by about $15 \mathrm{~km}$ with respect to our observations. Moreover, if GLORYS12V1 represents the upward extent of the core in austral autumn, the seasonality of the transport is reversed with respect to our observations. Thus, current GLORYS products therefore seem to have drawback in this near-coastal zone that prevent the use of this product as a reliable baseline.

As previously indicated, we observed similar patterns of SSH and surface geostrophic currents between the seasonal climatologies and the conditions observed during the surveys in the slope region (Figure 10). If we put the spring and fall conditions in perspective within the total seasonal cycle, we can see that these two seasons do correspond to contrasted states (Supplementary material Figure S6). We prepared maps of interpolated geostrophic current for spring 2015, fall 2017 and the climatology for spring and fall for the period 1993-2018 (Supplementary material Figure S7). On this basis, we first compared the seasonal differences (spring minus fall) for the periods of the two surveys and for the 1993-2018 climatologies. In the study area, the patterns are remarkably similar although, quite logically, the differences are a slightly more marked in the case of the spring 2015 - fall 2017 comparison than in that of the climatologies. Now if we compare the geostrophic currents of spring 2015 to the spring climatology and fall 2017 to the fall climatology, we also observe small differences in the study area.

\section{Discussion}


In this study, we used SADCP, CTDO and altimetry data to portray the ocean circulation over the continental slope of the NEB in austral spring 2015 and fall 2017. Our study is based on synoptic observations. Before discussing the results, it is important to investigate the representativeness of our data. Since re-analysis products (GLORYS12V1) showed to have limitations in this near-shore region, we could only base our comparison on geostrophic currents. The differences between the conditions observed in spring 2015 and fall 2017 with the climatological conditions for these seasons are small (Figure 10; Supplementary material Figure S7). In addition, using both direct observations and numerical simulations, Hummels et al. (2015) showed that the average transport of the North Brazil Undercurrent at $11^{\circ} \mathrm{S}$ did not change between 2000-2004 and 2013-2014. Moreover, Assunção et al. (2020) did not observe any significant differences in the thermohaline structure of the region during spring 2015 and fall 2017 when compared with the same periods from other years. For all these reasons we can reasonably consider that the conditions observed during the ABRAÇOS surveys in spring 2015 and fall 2017 are representative of the canonical conditions of spring and fall, which allows us to address seasonal changes to a certain extent. Using these data, we provide a high-resolution description of the NBUC characteristics in the two seasons and a comprehensive picture of the NBUC/NBC transition in fall.

\subsection{NBUC features and variability}

Current measurements acquired during surveys display the NBUC trapped along the NEB coast between $9^{\circ} \mathrm{S}$ and $5^{\circ} \mathrm{S}$ (Figures 6 and 7). Its maximum velocity is on average centred at approximately $200-300 \mathrm{~m}$ depth with velocity that can locally reach $1.2 \mathrm{~m} \mathrm{~s}^{-1}$ in spring 2015 , in accordance with Silveira et al. (1994). The NBUC carries equatorward high-salinity and oxygen-enriched South Atlantic Water (Bourlès et al. 1999a) (Figure 3) within its core and exhibits higher transport in spring than fall (Figures 4-9; Table 1). In the surface layer, transport was slightly higher in fall 2017 than in spring 2015 (Figure 8; Table 1) due to an observed shallower NBUC core in the fall. It is difficult to directly compare our results with previous studies since they were mostly performed at a specific latitude and period and with a variety of methods. In Table 1, we provide a synthesis of current transport from this and other studies. It shows that our results fall within previous measurements but provide a more detailed picture.

Between $9^{\circ} \mathrm{S}$ and $6^{\circ} \mathrm{S}$, the NBUC mean velocity and transport (Figures 4 to 7 ) were higher in spring 2015 than in fall 2017 (difference of $0.2 \mathrm{~m} \mathrm{~s}^{-1}$ in velocity and $5 \mathrm{~Sv}$ in transport). In addition, the vertical extent of the NBUC velocity core was higher in spring 2015 (110 $\mathrm{m}$ to more than $500 \mathrm{~m}$ depth) than in fall $2017(50-410 \mathrm{~m})$. These results bring additional information to previous studies based on both in situ data ( Stramma et al., 1995; Schott et al., 2005; Veleda et al., 2012; Hummels et al., 2015; Herrford et al., 2020) and numerical simulations (Rodrigues et al., 2007; Silva et al., 2009; Veleda et al., 2011; Herrford et al., 2020). These studies reported a seasonal variability of the near surface sSEC-NBUC-BC (BC for Brazil Current) system transports associated with changes in the local wind stress curl due to the annual north-south excursion of the Inter Tropical Convergence Zone. Indeed, in austral winter, the sSEC bifurcation latitude reaches its southernmost position, the NBUC transport is higher and BC transport is lower (e.g., Rodrigues et al., 2007; Silva et al., 2009). In contrast, the near surface sSEC bifurcation latitude is located at the northernmost position during summer, when the NBUC transport is seasonally lower and the BC transport is higher. The wind velocity follows this pattern with highest values $\left(>9 \mathrm{~m} \cdot \mathrm{s}^{-1}\right)$ between August and December and lowest velocities $\left(<8 \mathrm{~m} . \mathrm{s}^{-1}\right)$ in April-May (Domingues et al., 2017).

The equatorward increase in NBUC strength was accompanied by an increase in its core (Figure 7a, b). As previously described (e.g., Schott et al., 1998), this upward pattern is attributed to the Ekman drift, which is less intense north of the area (Stramma et al., 1995). Indeed, the westerly-driven Ekman drift is southwestward in the region, constraining the 
equatorward flow to the subsurface from its origin to approximately $5^{\circ} \mathrm{S}$, from where it decreases.

Another reason for the latitudinal variation in the NBUC along the NEB continental slope is the orography effect. Whatever the season, we observed a change in the zonal flow, shifting from eastward south of $7.5^{\circ} \mathrm{S}$ to westward farther north (Figure 5a, b), and the intensification of the equatorward flow between $8^{\circ} \mathrm{S}$ and $7^{\circ} \mathrm{S}$ (Figures $4 \mathrm{c}$, f and 5). This consistency suggests that the coastal curvature affects the mean nearshore circulation characteristics. In fact, using a two-layer model, Ou and De Ruijter (1986) pointed out that boundary currents are subjected to a separation where a positive coastal curvature occurs. Their calculation showed that the separation is dominantly controlled by inertial and beta effects.

\subsection{NBUC/NBC transition}

The region located north of $5^{\circ} \mathrm{S}$, between $36.5^{\circ} \mathrm{W}$ and $34.5^{\circ} \mathrm{W}$, is a crucial transition area where the SEUC and the NBC (Schott et al., 1998; Bourlès et al., 1999a, b; Goes et al., 2005 ) originate. Here, we provide a comprehensive description of the NBUC/NBC transition, its interaction with the cSEC, and further evidences about the origin of the SEUC. The image we propose is based on fall 2017 data only, but the feature and position of this transition should not significantly vary according to the season. Indeed, surface currents are stronger in this transitional area during fall than spring, but the position where the geostrophic current increases is alike (Supplementary material, Figures S5 and S6). In this area, the NBUC and the cSEC coalesce to form the NBC (Figure 9) as already depicted by previous works (Stramma et al., 1995; Bourlès et al., 1999b; Schott et al., 1995, 1998). Moving to the west, a clear distinction between the NBC and the cSEC is no longer possible in the upper layer.

More precisely, the mean NBUC inflow crossing $5^{\circ} \mathrm{S}$ in the surface layer $(0-70 \mathrm{~m})$ was up to $1.8 \mathrm{~Sv}$ (Figure 8). North of this latitude $\left(5^{\circ} \mathrm{S}-3.3^{\circ} \mathrm{S}\right)$, at $35^{\circ} \mathrm{W}$, this upper layer transport increased to $7.6 \pm 0.8 \mathrm{~Sv}$. The observed rapid increase in surface transport at $5^{\circ} \mathrm{S}$ is due to the cSEC input, that overlies the NBUC (Figure 9a, b). Thus, the net contribution of the cSEC to the surface western boundary flow is the difference between the upper layer transports observed at $5^{\circ} \mathrm{S}(1.8 \mathrm{~Sv})$ and $35^{\circ} \mathrm{W}(7.6 \mathrm{~Sv})$. Therefore, this contribution is $5.8 \mathrm{~Sv}$. These results agree with previous studies (Table 1). In particular, Schott et al. (2003) estimated the cSEC transport between $4^{\circ} \mathrm{S}$ and $2.5^{\circ} \mathrm{S}$ up to $7 \mathrm{~Sv}$ above the $\sigma_{\theta}=24.5$ isopycnal $(70 \mathrm{~m})$. 
Table 1. Synthesis of transport (in Sv) estimations in the upper and lower layers (the precise depth range is provided in each case) across sections between $10^{\circ} \mathrm{S}$ and $3^{\circ} \mathrm{S}$ over the continental slope of the Northeast Brazil from this and previous works. The longitudinal extent of the sections is expressed in longitude or in distance from the shelf break. In some sections north of $5^{\circ} \mathrm{S}$ we observed both a westward zonal transport corresponding to the NBUC/NBC system and a zonal eastward transport corresponding to the SEUC. In this case we added, in bold, the transport calculation related to the SEUC. Note that in Stramma et al. (1995), the calculated transport corresponds to the geostrophic transport computed from CTD data.

\begin{tabular}{|c|c|c|c|c|c|}
\hline Reference & Sections & Upper layer & Lower layer & Total transport & Period \\
\hline This study & $9^{\circ} \mathrm{S}-6^{\circ} \mathrm{S}, 0-40 \mathrm{~km}$ & $0.8 \pm 0.4(0-70 \mathrm{~m})$ & $19.4 \pm 2.3(70-350 \mathrm{~m})$ & $115.6 \pm 4.3(0-500 \mathrm{~m})$ & Spring (Sept. -Oct.) 2015 \\
\hline This study & $9^{\circ} \mathrm{S}-8^{\circ} \mathrm{S}, 0-55 \mathrm{~km}$ & $0.8 \pm 0.3(0-70 \mathrm{~m})$ & $8.7 \pm 2.2(70-350 \mathrm{~m})$ & $14.9 \pm 4.8(0-500 \mathrm{~m})$ & Spring (Sept. -Oct.) 2015 \\
\hline This study & $8^{\circ} \mathrm{S}-7^{\circ} \mathrm{S}, 0-20 \mathrm{~km}$ & $0.5 \pm 0.2(0-70 \mathrm{~m})$ & $8.1 \pm 0.9(70-350 \mathrm{~m})$ & $112.8 \pm 1.7(0-500 \mathrm{~m})$ & Spring (Sept. -Oct.) 2015 \\
\hline This study & $7^{\circ} \mathrm{S}-6^{\circ} \mathrm{S}, 0-30 \mathrm{~km}$ & $0.8 \pm 0.3(0-70 \mathrm{~m})$ & $7.8 \pm 1.4(70-350 \mathrm{~m})$ & $112.9 \pm 2.5(0-500 \mathrm{~m})$ & Spring (Sept. -Oct.) 2015 \\
\hline This study & $9^{\circ} \mathrm{S}-6^{\circ} \mathrm{S}, 0-40 \mathrm{~km}$ & $1.3 \pm 0.4(0-70 \mathrm{~m})$ & $8.0 \pm 1.8(70-350 \mathrm{~m})$ & $11.0 \pm 2.6(0-500 \mathrm{~m})$ & Fall (April- May) 2017 \\
\hline This study & $9^{\circ} \mathrm{S}-8^{\circ} \mathrm{S}, 0-35 \mathrm{~km}$ & $0.8 \pm 0.4(0-70 \mathrm{~m})$ & $5.8 \pm 1.2(70-350 \mathrm{~m})$ & $19.2 \pm 2.0(0-500 \mathrm{~m})$ & Fall (April- May) 2017 \\
\hline This study & $8^{\circ} \mathrm{S}-7^{\circ} \mathrm{S}, 0-50 \mathrm{~km}$ & $1.7 \pm 0.3(0-70 \mathrm{~m})$ & $10.5 \pm 1.3(70-350 \mathrm{~m})$ & $15.3 \pm 2.5(0-500 \mathrm{~m})$ & Fall (April- May) 2017 \\
\hline This study & $7^{\circ} \mathrm{S}-6^{\circ} \mathrm{S}, 0-50 \mathrm{~km}$ & $1.8 \pm 0.3(0-70 \mathrm{~m})$ & $10.4 \pm 1.2(70-350 \mathrm{~m})$ & $15.6 \pm 2.4(0-500 \mathrm{~m})$ & Fall (April- May) 2017 \\
\hline This study & $6^{\circ} \mathrm{S}-5^{\circ} \mathrm{S}, 0-35 \mathrm{~km}$ & $2.1 \pm 0.4(0-70 \mathrm{~m})$ & $11.4 \pm 1.6(0-350 \mathrm{~m})$ & $16.8 \pm 1.7(0-500 \mathrm{~m})$ & Fall (April- May) 2017 \\
\hline This study & $5^{\circ} \mathrm{S}-3.3^{\circ} \mathrm{S}, 34.7^{\circ} \mathrm{W}-35.3^{\circ} \mathrm{W}$ & $7.6 \pm 0.8(0-70 \mathrm{~m})$ & $15.8 \pm 4.6(70-350 \mathrm{~m})$ & - & Fall (April- May) 2017 \\
\hline This study & $\begin{array}{c}3.8^{\circ} \mathrm{S}-3.3^{\circ} \mathrm{S}, 34.7^{\circ} \mathrm{W}- \\
35.3^{\circ} \mathrm{W}\end{array}$ & - & $2.6 \pm 1.2(120-330 \mathrm{~m})$ & - & Fall (April- May) 2017 \\
\hline This study & $5^{\circ} \mathrm{S}-3.3^{\circ} \mathrm{S}, 35.3^{\circ} \mathrm{W}-36^{\circ} \mathrm{W}$ & $8.7 \pm 1.1(0-70 \mathrm{~m})$ & $14.2 \pm 4.2(70-350 \mathrm{~m})$ & - & Fall (April- May) 2017 \\
\hline This study & $5^{\circ} \mathrm{S}-3.3^{\circ} \mathrm{S}, 35.3^{\circ} \mathrm{W}-36^{\circ} \mathrm{W}$ & - & $0.6 \pm 0.1(150-300 \mathrm{~m})$ & - & Fall (April- May) 2017 \\
\hline This study & $34.7^{\circ} \mathrm{W}, 3.3^{\circ} \mathrm{S}-3.8^{\circ} \mathrm{S}$ & $1.9 \pm 0.1(0-70 \mathrm{~m})$ & $0.7 \pm 0.0(70-350 \mathrm{~m})$ & $2.8 \pm 0.2(0-600 \mathrm{~m})$ & Fall (April- May) 2017 \\
\hline This study & $34.7^{\circ} \mathrm{W}, 3.3^{\circ} \mathrm{S}-3.8^{\circ} \mathrm{S}$ & - & $2.1 \pm 0.1(140-600 \mathrm{~m})$ & - & Fall (April- May) 2017 \\
\hline This study & $35^{\circ} \mathrm{W}, 3.3^{\circ} \mathrm{S}-4.1^{\circ} \mathrm{S}$ & $4.5 \pm 0.1(0-70 \mathrm{~m})$ & $1.7 \pm 0.4(70-350 \mathrm{~m})$ & $7.9 \pm 0.9(0-600 \mathrm{~m})$ & Fall (April- May) 2017 \\
\hline This study & $35^{\circ} \mathrm{W}, 3.3^{\circ} \mathrm{S}-4.1^{\circ} \mathrm{S}$ & - & $3.4 \pm 0.7(120-570 \mathrm{~m})$ & - & Fall (April- May) 2017 \\
\hline This study & $35.4^{\circ} \mathrm{W}, 3.3^{\circ} \mathrm{S}-4.1^{\circ} \mathrm{S}$ & $5.6 \pm 0.1(0-70 \mathrm{~m})$ & $13.9 \pm 0.5(70-350 \mathrm{~m})$ & $21.6 \pm 1.2(0-600)$ & Fall (April- May) 2017 \\
\hline
\end{tabular}




\begin{tabular}{|c|c|c|c|c|c|}
\hline This study & $35.4^{\circ} \mathrm{W}, 3.3^{\circ} \mathrm{S}-4.1^{\circ} \mathrm{S}$ & - & $0.4 \pm 0.1(100-350 \mathrm{~m})$ & - & Fall (April- May) 2017 \\
\hline This study & $35.7^{\circ} \mathrm{W}, 3.3^{\circ} \mathrm{S}-4.1^{\circ} \mathrm{S}$ & $6.1 \pm 0.3(0-70 \mathrm{~m})$ & $12.4 \pm(70-350 \mathrm{~m})$ & $23.6 \pm(0-600 \mathrm{~m})$ & Fall (April- May) 2017 \\
\hline This study & $35.7^{\circ} \mathrm{W}, 3.3^{\circ} \mathrm{S}-4.1^{\circ} \mathrm{S}$ & - & $0.2 \pm 0.0(150-400 \mathrm{~m})$ & - & Fall (April- May) 2017 \\
\hline This study & $36^{\circ} \mathrm{W}, 3.3^{\circ} \mathrm{S}-4.1^{\circ} \mathrm{S}$ & $6.3 \pm 0.1(0-70 \mathrm{~m})$ & $18.5 \pm 1.2(70-350 \mathrm{~m})$ & $32.1 \pm 2.7(0-600 \mathrm{~m})$ & Fall (April- May) 2017 \\
\hline This study & $36.4^{\circ} \mathrm{W}, 3.3^{\circ} \mathrm{S}-4.1^{\circ} \mathrm{S}$ & $6.3 \pm 0.1(0-70 \mathrm{~m})$ & $22.8 \pm 1.1$ & $39.5 \pm 3.2(0-600 \mathrm{~m})$ & Fall (April- May) 2017 \\
\hline \multirow[t]{2}{*}{ Silveira et al. (1994) } & $7^{\circ} \mathrm{S}, 34.5^{\circ} \mathrm{W}-32^{\circ} \mathrm{W}$ & $9.1(0-150 \mathrm{~m})$ & - & $17.3(0-500 \mathrm{~m})$ & May-July 1986 \\
\hline & $8.5^{\circ} \mathrm{S}, 34.6^{\circ} \mathrm{W}-33^{\circ} \mathrm{W}$ & $8.3(0-150 \mathrm{~m})$ & - & $20.4(0-500 \mathrm{~m})$ & May-July 1986 \\
\hline \multirow[t]{5}{*}{ Schott et al. (1998) } & $5^{\circ} \mathrm{S}, 35^{\circ} \mathrm{W}-32.5^{\circ} \mathrm{W}$ & $1.8(0-70 \mathrm{~m})$ & $11.7(70-350 \mathrm{~m})$ & - & Oct. 1990 \\
\hline & $5^{\circ} \mathrm{S}, 35^{\circ} \mathrm{W}-32^{\circ} \mathrm{W}$ & $2.1(0-70 \mathrm{~m})$ & $11.1(70-350 \mathrm{~m})$ & - & March 1994 \\
\hline & $5^{\circ} \mathrm{S}, 35^{\circ} \mathrm{W}-32.5^{\circ} \mathrm{W}$ & $2.6(0-70 \mathrm{~m})$ & $8.2(70-350 \mathrm{~m})$ & - & Oct. 1992 \\
\hline & $10^{\circ} \mathrm{S}, 35^{\circ} \mathrm{W}-32.5^{\circ} \mathrm{W}$ & $0.8(0-70 \mathrm{~m})$ & $11.7(70-350 \mathrm{~m})$ & - & Oct. 1992 \\
\hline & $10^{\circ} \mathrm{S}, 35^{\circ} \mathrm{W}-32^{\circ} \mathrm{W}$ & $0.6(0-70 \mathrm{~m})$ & $9(70-350 \mathrm{~m})$ & - & March 1994 \\
\hline Schott et al. (2002) & $5^{\circ} \mathrm{S}, 35^{\circ} \mathrm{W}-33^{\circ} \mathrm{W}$ & $2.7 \pm 1.8(0-70 \mathrm{~m})$ & $13.4 \pm 2.7(70-350 \mathrm{~m})$ & - & Mean of 6 sections ( $1990 \& 2000)$ \\
\hline \multirow[t]{3}{*}{ Goes et al. (2005) } & $5^{\circ} \mathrm{S}, 35^{\circ} \mathrm{W}-34^{\circ} \mathrm{W}$ & $2.3(0-70 \mathrm{~m})$ & $12.3(70-350 \mathrm{~m})$ & - & Feb. 2002 \\
\hline & $35^{\circ} \mathrm{W}, 5.2^{\circ} \mathrm{S}-3.8^{\circ} \mathrm{S}$ & $6.5(0-70 \mathrm{~m})$ & $16.9(70-350 \mathrm{~m})$ & - & Feb. 2002 \\
\hline & $35^{\circ} \mathrm{W}, 4^{\circ} \mathrm{S}-2^{\circ} \mathrm{S}$ & - & $3.3(120-405 \mathrm{~m})$ & - & Feb. 2002 \\
\hline \multirow[t]{3}{*}{ Stramma et al. (1995) } & $5.5^{\circ} \mathrm{S}, 35^{\circ} \mathrm{W}-33.5^{\circ} \mathrm{W}$ & $2.9(0-100 \mathrm{~m})$ & & $19.3(0-500 \mathrm{~m})$ & Oct. 1990 \\
\hline & $5.5^{\circ} \mathrm{S}, 35^{\circ} \mathrm{W}-32.46^{\circ} \mathrm{W}$ & $2.9(0-100 \mathrm{~m})$ & & $19.3(0-500 \mathrm{~m})$ & Nov. 1992 \\
\hline & $10^{\circ} \mathrm{S}, 35.5^{\circ} \mathrm{W}-34.25^{\circ} \mathrm{W}$ & $2.5(0-100 \mathrm{~m})$ & - & $16.0(0-500 \mathrm{~m})$ & Nov. 1992 \\
\hline Bourlès et al. (1999b) & $5^{\circ} \mathrm{S}, 35^{\circ} \mathrm{W}-34^{\circ} \mathrm{W}$ & $3.8(0-70 \mathrm{~m})$ & $10.6(70-350 \mathrm{~m})$ & - & Feb. 1993 \\
\hline Bourlès et al. (1999b) & $35^{\circ} \mathrm{W}, 4^{\circ} \mathrm{S}-3^{\circ} \mathrm{S}$ & - & $3.1(70-350 \mathrm{~m})$ & - & Feb. 1993 \\
\hline Bourlès et al. (1999b) & $35^{\circ} \mathrm{W}, 5^{\circ} \mathrm{S}-2^{\circ} \mathrm{S}$ & $8.6(0-70 \mathrm{~m})$ & $15.6(70-350 \mathrm{~m})$ & - & April 1996 \\
\hline Bourlès et al. (1999b) & $35^{\circ} \mathrm{W}, 4^{\circ} \mathrm{S}-3^{\circ} \mathrm{S}$ & & $2.1(70-350 \mathrm{~m})$ & & April 1996 \\
\hline Schott et al. (1995) & $35^{\circ} \mathrm{W}, 5^{\circ} \mathrm{S}-3.2^{\circ} \mathrm{S}$ & $5.1(0-70 \mathrm{~m})$ & $13.1(70-350 \mathrm{~m})$ & - & March 1994 \\
\hline Schott et al. (2005) & $5^{\circ} \mathrm{S}, 35^{\circ} \mathrm{W}-32^{\circ} \mathrm{W}$ & $3.8(0-70 \mathrm{~m})$ & $14.2(70-350 \mathrm{~m})$ & - & Mean of 9 sections (2000-2004) \\
\hline
\end{tabular}


One overarching question in the literature is the development of the NBUC after crossing $5^{\circ} \mathrm{S}$. It is known that after the generation of the NBC in the upper layer, a subsurface part of the NBUC continues flowing in the same direction as the NBC (e.g., Bourlès et al., 1999b). The increase in NBUC transport from 6.1-11.5 Sv (Figure 8) south of $5^{\circ} \mathrm{S}$ to $15.8 \pm 4.6$ Sv north of this latitude at $35^{\circ} \mathrm{W}$ (Table 1 , this study) implies that the contribution of the cSEC to the western boundary equatorward flow is not restricted to the upper layer. The subsurface cSEC contribution maintains the NBUC flow northwestward after the formation of the NBC in the upper layer (Bourlès et al., 1999b; Goes et al., 2005).

On the other hand, there is still no consensus on the origins of the SEUC. Schott et al. (2002) found that high oxygen values in the SEUC suggest a western boundary origin, while Schott et al. $(1995,1998)$ did not observe any contribution of the NBUC to the SEUC and rather suggested that the SEUC originates from the SEC recirculation. Our results help to settle the debate. North of $3.8^{\circ} \mathrm{S}$, at $35^{\circ} \mathrm{W}$, the core of the SEUC extends from 120-330 m depth with velocity up to $0.2 \mathrm{~m} \mathrm{~s}^{-1}$ and transports $2.6 \pm 1.2 \mathrm{~Sv}$ (Figure $9 \mathrm{~b}$ ), also in accordance with previous studies (e.g., Bourlès et al., 1999b; Schott et al., 2003; Goes et al., 2005). Our hydrographic data show that the water mass at $3.8^{\circ} \mathrm{S}, 35^{\circ} \mathrm{W}$ (Figure 11c), corresponding to SEUC, is oxygendepleted in the subsurface, contrary to the NBUC, which is characterized by a high oxygen content (Figure 11a, b). This illustrates that the SEUC is actually supplied by interior recirculation of the near-equator cSEC, and eSEC waters from the east, as proposed by Schott et al. $(1995,1998,2002)$, and not by the NBUC. On the other hand, the eastward flow observed at $35.8^{\circ} \mathrm{W}$, south of $4.4^{\circ} \mathrm{S}$ at $\sim 100-600 \mathrm{~m}$ (Figure $9 \mathrm{c}$ ), is not well documented, probably because of a lack of data close to the coast. This flow pattern may be due to the topographic effect on the large-scale circulation.

\subsection{Impact of Mesoscale activity}

We also report the impact of mesoscale activity on the mean nearshore circulation of the NEB region. In spring 2015, an anticyclonic eddy centred at $8.5^{\circ} \mathrm{S}$ between $35^{\circ} \mathrm{S}$ and $34^{\circ} \mathrm{W}$ (Figure 10b, Supplementary material Figure S2) locally weakened the nearshore circulation in the NEB area (Figure 4c). In fall 2017, a cyclonic eddy centred at $33^{\circ} \mathrm{W}, 8.8^{\circ} \mathrm{S}$ slightly enhanced the nearshore surface circulation in the extreme southern part of the survey area (Figures 10, Supplementary material Figure S3). Such mesoscale eddy impacts on large-scale circulation with weakening or intensification of local circulation have already been evidenced in western (Ma et al., 2016) and eastern (Chaigneau et al., 2013; Czeschel et al., 2011) boundary systems in the Pacific Ocean, but never in the western boundary along the NEB.

\section{Summary and Conclusion}

The western boundary currents offshore Brazil are a key region of wind and thermohaline-induced circulation in the Atlantic Ocean. This part of the ocean works as a kind of "highway", where important components of the Atlantic meridional overturning circulation (AMOC) and the Atlantic subtropical cell meet. Direct observations along the Northeast Brazil shoreline confirm the southward transport of cold deep waters associated with the northward transport of warm and intermediate waters through the Northern Brazilian Undercurrent. Considering this geophysical situation important scientific efforts have been achieved (Schott et al., 2003, 2005; Hummels et al., 2015; Herrford et al., 2020Bourlès et al., 2019; Foltz et al., 2019). Although all these efforts have been notable, there were still a lack of information about the spatial variability of the western boundary circulation along the Northeast Brazilian coast.

This study complement the understanding of the dynamics of the western boundary currents in the south tropical Atlantic, including the NBUC/NBC system in two seasons. By 
continuous coverage along the NEB continental slope $\left(9.4^{\circ} \mathrm{S}-3.4^{\circ} \mathrm{S}\right)$, we fill the gap left by previous works that mostly focused on few specific latitudes, as above discussed. We describe the seasonal and spatial variations in NBUC characteristics resulting from ocean-atmosphere processes, orographic effects, and mesoscale activity. In addition, we describe in detail the NBUC/NBC transition and settle the debate about the origin of the SEUC. From these results, we propose an updated description of the shallow western boundary circulation along the NEB (Figure 1). The NBUC originating south of $10^{\circ} \mathrm{S}$ flows equatorward over the continental slope in the NEB region. This equatorward flow is locally influenced by mesoscale activity. The orographic effect shifts the zonal flow from eastward south of $7.5^{\circ} \mathrm{S}$ to westward north of $7.5^{\circ} \mathrm{S}$. At $\sim 4.8^{\circ} \mathrm{S}$, the cSEC enters the equatorward flow system where it coalesces with the NBUC to form the NBC, which flows northwestward toward the Caribbean Sea. In the subsurface layer, the NBUC continues flowing together with NBC, after receiving the cSEC contribution in the subsurface. Finally, contrary to what had been proposed by some authors (e.g., Bourlès et al., 1999) the NBUC retroflection does not aliment the SEUC, which, instead, is originated by retroflections of the eSEC and the cSEC.

Recently, a decadal increase in salinity in the central waters at $11^{\circ} \mathrm{S}$ off Brazil has been detected (Hummels et al., 2015). In addition, different numerical experiments suggested a trend to an increase in Agulhas leakage (Chang et al., 2008; Biastoch et al., 2009; Zhang et al., 2011). In this context of changing ocean, the more comprehensive description of the western boundary circulation off Northeast Brazil presented herein will also certainly serve as a reference for diagnosing future variations in the upper/warm tropical branch of the Atlantic Meridional Overturning Circulation - AMOC.

\section{Acknowledgments}

We acknowledge the French oceanographic fleet for funding ABRAÇOS 1 and 2 ship-time and the officers and crew of the R/V Antea for their contribution to the success of the operations. Pierre Lopez (IRD, MARBEC) is thanked for editing Figure 1. This work was supported by the CAPES (Coordenação de Aperfeiçoamento de Pessoal de Nível Superior) through a PhD scholarship grant for A.N.D. M.A. appreciates the support of the Brazilian Research Network on Global Climate Changes - Rede CLIMA (FINEP-CNPq 437167/2016-0) and the Brazilian National Institute of Science and Technology for Tropical Marine Environments - INCT AmbTropic (CNPq/FAPESB 565054/2010-4 and 8936/2011). This work is a contribution to the International Joint Laboratory TAPIOCA (www.tapioca.ird.fr), to the SMAC project (CAPES/COFECUB $n^{\circ} 88881.142689 / 2017-01$ ), the PADDLE project (funding by the European Union's Horizon 2020 research and innovation programme - grant agreement No. 73427), and to the TRIATLAS project, which has also received funding from the European Union's Horizon 2020 research and innovation program under grant agreement No 817578. 


\section{References}

Ablain, M., Cazenave, A., Larnicol, G., Balmaseda, M., Cipollini, P., Faugère, Y., Fernandes, M.J., Henry, O., Johannessen, J.A., Knudsen, P., Andersen, O., Legeais, J., Meyssignac, B., Picot, N., Roca, M., Rudenko, S., Scharffenberg, M.G., Stammer, D., Timms, G., Benveniste, J., 2015. Improved sea level record over the satellite altimetry era (1993-2010) from the Climate Change Initiative project. Ocean Science 11, 67-82. https://doi.org/10.5194/os-11-67-2015

Arhan, M., Mercier, H., Bourlès, B., Gouriou, Y., 1998. Hydrographic sections across the Atlantic at $7^{\circ} 30 \mathrm{~N}$ and $4^{\circ} 30 \mathrm{~S}$. Deep-Sea Research Part I: Oceanographic Research Papers 45, 829-872. https://doi.org/10.1016/S0967-0637(98)00001-6

Assunção, R.V., Costa da Silva, A., Roy, A., Bourlès, B., Silva, C.H., Ternon, J.F., Araujo, M., Bertrand A., 2020. 3D characterisation of the thermohaline structure in the southwestern tropical Atlantic derived from functional data analysis of in situ profiles. Progress in Oceanography, 187: 102399. https://doi.org/10.1016/j.pocean.2020.102399.

Bertrand A. 2015. ABRACOS Cruise, RV Antea, https://doi.org/10.17600/15005600.

Bertrand A. 2017. ABRACOS 2 Cruise, RV Antea, https://doi.org/10.17600/17004100.

Biastoch, A., Böning, C.W., Schwarzkopf, F.U., Lutjeharms, J.R.E., 2009. Increase in Agulhas leakage due to poleward shift of Southern Hemisphere westerlies. Nature 462, 495-498. https://doi.org/10.1038/nature08519

Bourlès, B., D’Orgeville, M., Eldin, G., Gouriou, Y., Chuchla, R., DuPenhoat, Y., Arnault, S., 2002. On the evolution of the thermocline and subthermocline eastward currents in the Equatorial Atlantic. Geophysical Research Letters 29, 32-1-32-4. https://doi.org/10.1029/2002GL015098

Bourlès, B, Gouriou, Y., Chuchla, R., 1999a. On the circulation in the upper layer of the western equatorial Atlantic. Journal of Geophysical Research: Oceans 104, 2115121170. https://doi.org/10.1029/1999JC900058

Bourlès, B., Molinari, R.L., Johns, E., Wilson, W.D., 1999b. Upper layer currents in the western tropical North Atlantic (1989-1991). Journal of Geophysical Research 104, $1361-1375$.

Bourles, B., Molinari, R.L., Johns, E., Wilson, W.D., Leaman, K.D., 2002. Upper layer currents in the western tropical North Atlantic (1989-1991). Journal of Geophysical Research: Oceans 104, 1361-1375. https://doi.org/10.1029/1998jc900025

Bourlès, B., Araujo, M., McPhaden, M. J., Brandt, P., Foltz, G. R., Lumpkin, R., .Giordani, H., Hernandez, F., Lefèvre, N., Nobre, P., Campos, E. Saravanan, R., Trotte-Duhà, J., Dengler, M., Hahn, J., Hummels, R., Lübbecke, J.F., Rouaut, M., Citrim, L., Sutton, A., Jochum, M., Perez, R.C., 2019. PIRATA: A sustained observing system for tropical Atlantic climate research and forecasting. Earth and Space Science, 6(4), 577616. https://doi.org/10.1029/2018EA000428

Chaigneau, A., Dominguez, N., Eldin, G., Vasquez, L., Flores, R., Grados, C., Echevin, V., 2013. Near-coastal circulation in the Northern Humboldt Current System from shipboard ADCP data. Journal of Geophysical Research: Oceans 118, 5251-5266. https://doi.org/10.1002/jgrc.20328

Chang, P., Zhang, R., Hazeleger, W., Wen, C., Wan, X., Ji, L., Haarsma, R.J., Breugem, W.P., Seidel, H., 2008. Oceanic link between abrupt changes in the north Atlantic ocean and the African monsoon. Nature Geoscience 1, 444-448. https://doi.org/10.1038/ngeo218

Chelton, D.B., Schlax, M.G., Samelson, R.M., 2011. Global observations of nonlinear mesoscale eddies. Progress in Oceanography 91, 167-216. https://doi.org/10.1016/j.pocean.2011.01.002 
Chelton, D.B., Schlax, M.G., Samelson, R.M., de Szoeke, R.A., 2007. Global observations of large oceanic eddies. Geophysical Research Letters 34, 1-5. https://doi.org/10.1029/2007GL030812

Czeschel, R., Stramma, L., Schwarzkopf, F.U., Giese, B.S., Funk, A., Karstensen, J., 2011. Middepth circulation of the eastern tropical South Pacific and its link to the oxygen minimum zone. Journal of Geophysical Research: Oceans 116, 1-13. https://doi.org/10.1029/2010JC006565

da Silveira, I.C.A., de Miranda, L.B., Brown, W.S., 1994. On the origins of the North Brazil Current. Journal of Geophysical Research 99, 22501. https://doi.org/10.1029/94JC01776

Domingues, E. de C., Schettini, C.A.F., Truccolo, E.C., Oliveira Filho, J.C. de, 2017. Hydrography and currents on the Pernambuco Continental Shelf. Rbrh 22. https://doi.org/10.1590/2318-0331.0217170027

Dupuy, S., Pujol, M.-I., Picot, N., Ablain, M., Faugère, Y., Taburet, G., Pelloquin, C., 2016. DUACS DT2014: the new multi-mission altimeter data set reprocessed over 20 years. Ocean Science 12, 1067-1090. https://doi.org/10.5194/os-12-1067-2016

Foltz, G.R., Brandt, P., Richter, I., Rodriguez-Fonseca, B., Hernandez, F., Dengler, M., Rodrigues, R.R., ..., Reul, N., 2019. The tropical Atlantic observing system. Frontiers in Marine Science, 6, 206. https://doi.org/10.3389/fmars.2019.00206

Garzoli, S.L., 2004. North Brazil Current retroflection and transports. Journal of Geophysical Research 109, C01013. https://doi.org/10.1029/2003JC001775

Goes, M., Molinari, R., Da Silveira, I., Wainer, I., 2005. Retroflections of the North Brazil Current during February 2002. Deep-Sea Research Part I: Oceanographic Research Papers 52, 647-667. https://doi.org/10.1016/j.dsr.2004.10.010

Gouriou, Y., 1995. ETAMBOT 1 cruise, RV Le Noroit, https://doi.org/10.17600/95030010

Gordon, A.L., 1986. Interocean exchange of thermocline water. Journal of Geophysical Research 91, 5037. https://doi.org/10.1029/JC091iC04p05037

Herrford, J., Brandt, P., Kanzow, T., Hummels, R., Araujo, M., Durgadoo, J.V., 2020. Seasonal variability of the Atlantic Meridional Overturning Circulation at $11^{\circ} \mathrm{S}$ inferred from bottom pressure measurements. Ocean Science Discussions, 1-37. https://doi.org/10.5194/os-2020-55

Hummels, R., Brandt, P., Dengler, M., Fischer, J., Araujo, M., Veleda, D., Durgadoo, J. V., 2015. Interannual to decadal changes in the western boundary circulation in the Atlantic at $11^{\circ} \mathrm{S}$. Geophysical Research Letters 42, 7615-7622. https://doi.org/10.1002/2015GL065254

Lumpkin, R., Garzoli, S.L., 2005. Near-surface circulation in the Tropical Atlantic Ocean. Deep-Sea Research Part I: Oceanographic Research Papers 52, 495-518. https://doi.org/10.1016/j.dsr.2004.09.001

Ma, X., Jing, Z., Chang, P., Liu, X., Montuoro, R., Small, R.J., Bryan, F.O., Greatbatch, R.J., Brandt, P., Wu, D., Lin, X., Wu, L., 2016. Western boundary currents regulated by interaction between ocean eddies and the atmosphere. Nature 535, 533-537. https://doi.org/10.1038/nature18640

McWilliams, J.C., 2008. The nature and consequences of oceanic eddies, in: Geophysical Monograph Series. pp. 5-15. https://doi.org/10.1029/177GM03

Neto, A.V.N., Da Silva, A.C., 2014. Seawater temperature changes associated with the North Brazil current dynamics. Ocean Dynamics 64, 13-27. https://doi.org/10.1007/s10236013-0667-4

Ou, H.W., De Ruijter, W.P.M., 1986. Separation of an Inertial Boundary Current from a Curved Coastline. Journal of Physical Oceanography 16, 280-289. https://doi.org/10.1175/1520-0485(1986)016<0280:SOAIBC $>2.0 . C O ; 2$ 
Peterson, R.G., Stramma, L., 1991. Upper-level circulation in the South Atlantic Ocean. Progress in Oceanography 26, 1-73. https://doi.org/10.1016/0079-6611(91)90006-8

Rodrigues, R.R., Rothstein, L.M., Wimbush, M., 2007. Seasonal Variability of the South Equatorial Current Bifurcation in the Atlantic Ocean: A Numerical Study. Journal of Physical Oceanography 37, 16-30. https://doi.org/10.1175/JPO2983.1

Rühs, S., Getzlaff, K., Durgadoo, J. V., Biastoch, A., Böning, C.W., 2015. On the suitability of North Brazil Current transport estimates for monitoring basin-scale AMOC changes. Geophysical Research Letters 42, 8072-8080. https://doi.org/10.1002/2015GL065695

Schmitz, W.J., McCartney, M.S., 1993. On the North Atlantic Circulation. Reviews of Geophysics 31, 29-49. https://doi.org/10.1029/92RG02583

Schott, F. a., Dengler, M., Zantopp, R., Stramma, L., Fischer, J., Brandt, P., 2005. The Shallow and Deep Western Boundary Circulation of the South Atlantic at $5^{\circ}-11^{\circ} \mathrm{S}$. Journal of Physical Oceanography 35, 2031-2053. https://doi.org/10.1175/JPO2813.1

Schott, F.A., Brandt, P., Hamann, M., Fischer, J., Stramma, L., 2002. On the boundary flow off Brazil at $5-10^{\circ} \mathrm{S}$ and its connection to the interior tropical Atlantic. Geophysical Research Letters 29, 21-1-21-4. https://doi.org/10.1029/2002GL014786

Schott, F.A., Dengler, M., Brandt, P., Affler, K., Fischer, J., Bourlès, B., Gouriou, Y., Molinari, R.L., Rhein, M., 2003. The zonal currents and transports at $35^{\circ} \mathrm{W}$ in the tropical Atlantic. Geophysical Research Letters 30, 35-38. https://doi.org/10.1029/2002GL016849

Schott, F.A., Fischer, J., Stramma, L., 1998. Transports and Pathways of the Upper-Layer Circulation in the Western Tropical Atlantic. Journal of Physical Oceanography 28, 1904-1928. https://doi.org/10.1175/1520-0485(1998)028<1904:TAPOTU $>2.0 . C O ; 2$

Schott, F.A., Stramma, L., Fischer, J., 1995. The warm water inflow into the western tropical Atlantic boundary regime, spring 1994. Journal of Geophysical Research 100, 24745. https://doi.org/10.1029/95JC02803

Silva, M., Araujo, M., Servain, J., Penven, P., Lentini, C.A.D., 2009. High-resolution regional ocean dynamics simulation in the southwestern tropical Atlantic. Ocean Modelling 30, 256-269. https://doi.org/10.1016/j.ocemod.2009.07.002

Soutelino, R.G., Da Silveira, I.C.A., Gangopadhyay, A., Miranda, J.A., 2011. Is the Brazil Current eddy-dominated to the north of $20^{\circ} \mathrm{S}$ ? Geophysical Research Letters 38, 1-5. https://doi.org/10.1029/2010GL046276

Stramma, L., England, M., 1999. On the water masses and mean circulation of the South Atlantic Ocean. Journal of Geophysical Research: Oceans 104, 20863-20883. https://doi.org/10.1029/1999JC900139

Stramma, L., Fischer, J., Reppin, J., 1995. The North Brazil Undercurrent. Deep-Sea Research Part I 42, 773-795. https://doi.org/10.1016/0967-0637(95)00014-W

Stramma, L., Schott, F., 1999. The mean flow field of the tropical Atlantic Ocean. Deep Sea Research Part II: Topical Studies in Oceanography 46, 279-303. https://doi.org/10.1016/S0967-0645(98)00109-X

Urbano, D.F., De Almeida, R.A.F., Nobre, P., 2008. Equatorial undercurrent and North equatorial countercurrent at $38^{\circ} \mathrm{W}$ : A new perspective from direct velocity data. Journal of Geophysical Research: Oceans 113, 1-16. https://doi.org/10.1029/2007JC004215

Veleda, D.R.A., Araujo, M., Silva, M., Montagne, R., Araújo, R., 2011. Seasonal and interannual variability of the southern south equatorial current bifurcation and meridional transport along the eastern Brazilian edge. Tropical Oceanography, 39(1), 27-59. 
Veleda, D., Araujo, M., Zantopp, R., Montagne, R., 2012. Intraseasonal variability of the North Brazil Undercurrent forced by remote winds. Journal of Geophysical Research: Oceans, 117(C11). https://doi.org/10.1029/2012JC008392

Zhang, D., Msadek, R., McPhaden, M.J., Delworth, T., 2011. Multidecadal variability of the North Brazil Current and its connection to the Atlantic meridional overturning circulation. Journal of Geophysical Research 116, C04012.

https://doi.org/10.1029/2010JC006812 
Figures and captions 


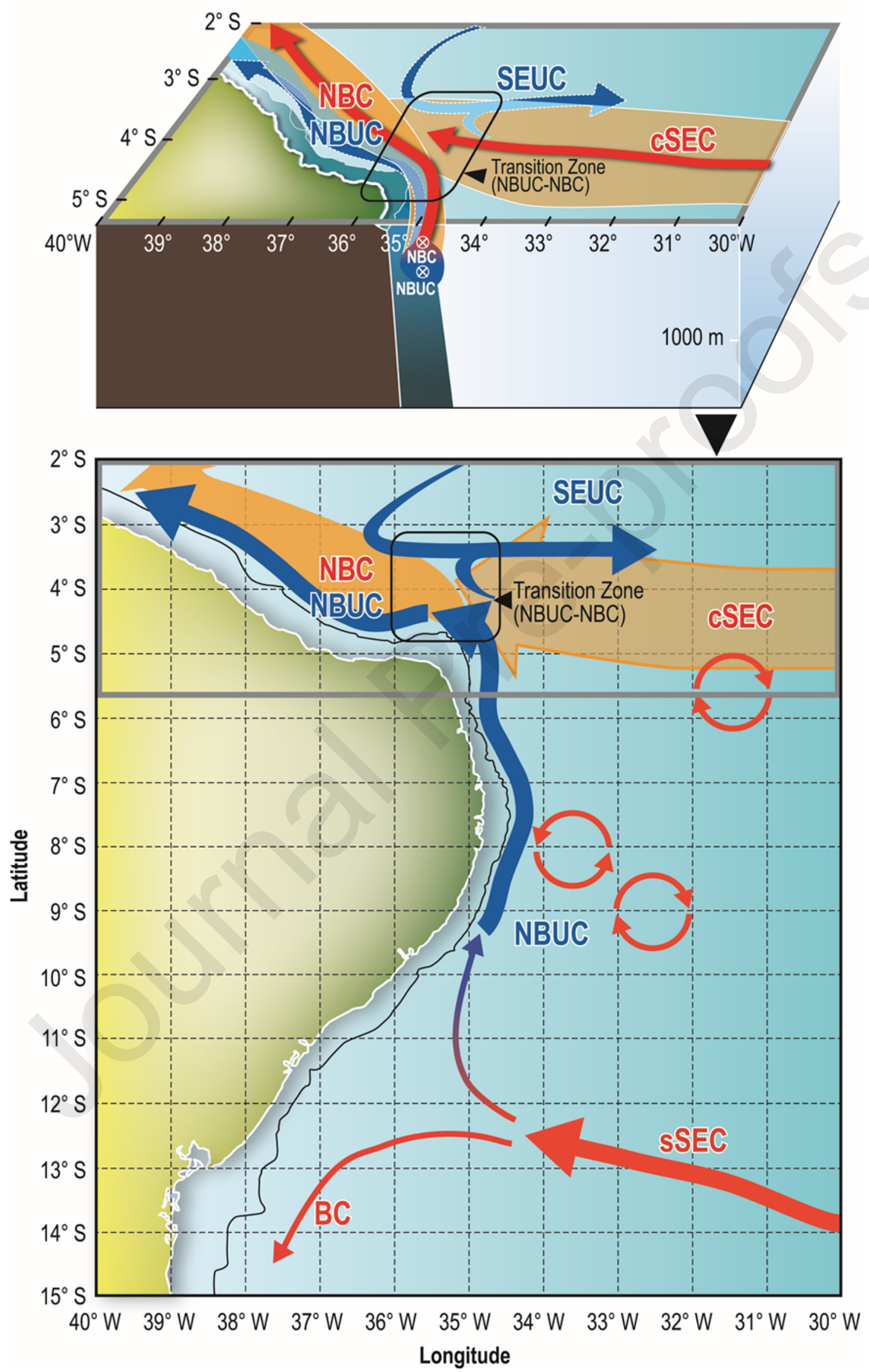


Figure 1. Schematic representation of mean currents and eddy generation along the Northeast Brazilian coast (lower panel) and a zoom (depicted by a grey rectangle) on the schematic circulation north of $5^{\circ} \mathrm{S}$ (upper panel). Surface currents in red and subsurface currents in blue. sSEC: southern branch of south equatorial current; BC: Brazil current; NBC: north Brazil current; SEUC: south equatorial undercurrent; NBUC: north Brazil undercurrent. The black rectangle indicates the NBUC-NBC transition zone. This figure summarizes the results of this study put into a wider context. 




Figure 2. Bathymetric maps of the study area with the SADCP ship tracks (black solid lines) obtained during surveys ABRAÇOS 1 in spring 2015 (a) and ABRAÇOS 2 in fall 2017 (b). Green circles indicate the positions of CTDO stations located off the shelf break and used in this work. Red circles indicate the CTDO stations used to discuss the current transition in the study area. The bold grey areas correspond to the shelf $(<70 \mathrm{~m})$. 

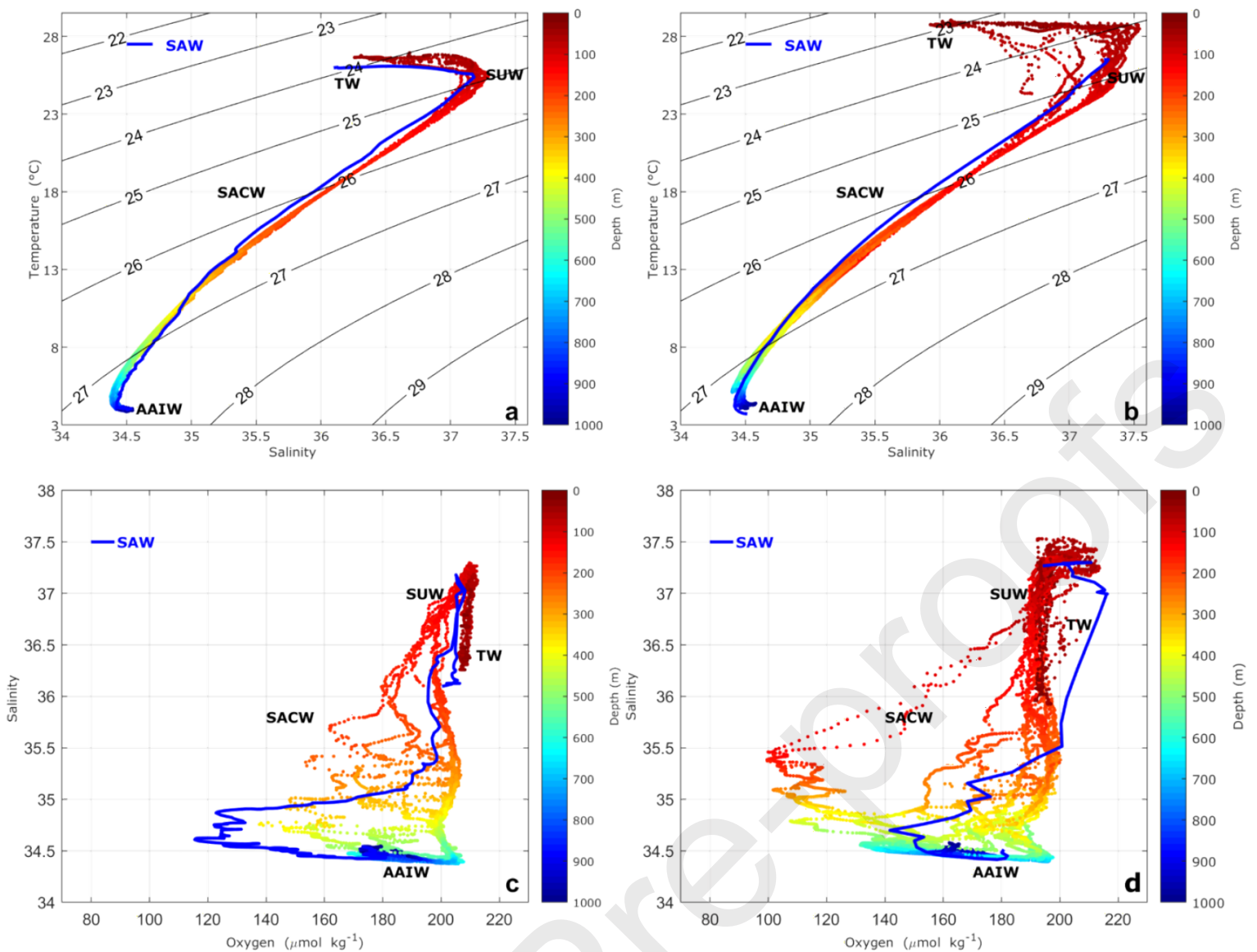

Figure 3. Temperature-salinity diagrams $(a, b)$ and salinity-oxygen curves $(c, d)$ from CTDO profiles obtained during the ABRAÇOS surveys in spring 2015 and fall 2017. The blue line represents typical South Atlantic water (SAW) profiles. Panels (a) and (c) correspond to spring 2015, while panels (c) and (d) correspond to fall 2017. TW: Tropical water; SUW: Subtropical Underwater; SACW: South Atlantic central water; AAIW: Antarctic intermediate water. 

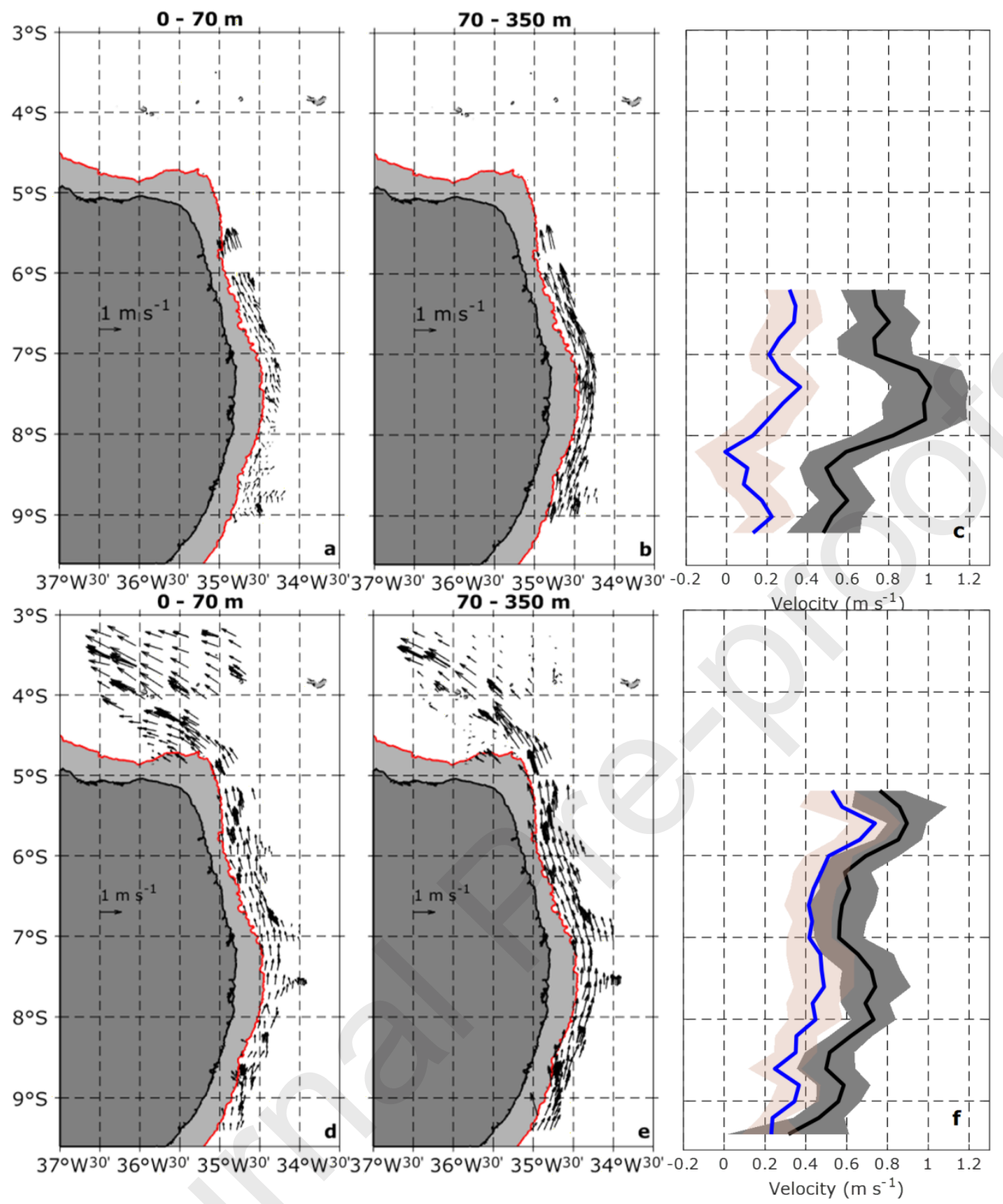

Figure 4. Mean current velocity obtained from SADCP profiles at 0-70 $\mathrm{m}(\mathrm{a}, \mathrm{d})$ and $70-350 \mathrm{~m}$ $(\mathrm{b}, \mathrm{e})$. The red line depicts the bathymetric contour at $70 \mathrm{~m}$. Meridional variation of the mean alongshore velocities at 0-70 $\mathrm{m}$ (blue line) and 70-350 m (black line) between the shelf break and $40 \mathrm{~km}$ offshore (c, f). Shaded grey and orange areas correspond to the standard deviation around the mean. The first row (a, b, c) corresponds to spring 2015, while the second row (d, e, f) corresponds to fall 2017. 

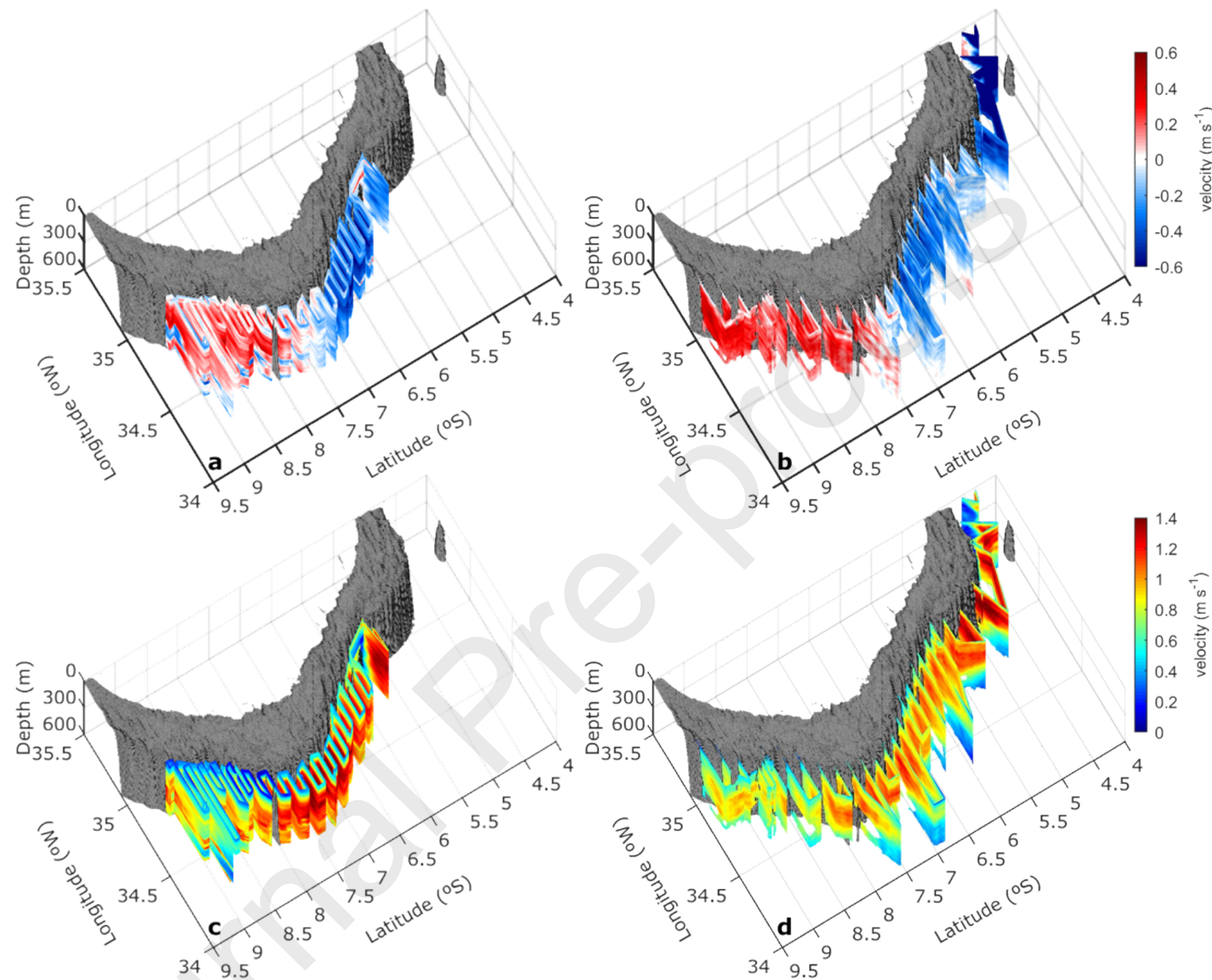

Figure 5. 3D representations of the zonal $(a, b)$ and meridional (c, d) flows during spring 2015 (a, c) and fall 2017 (b, d). 

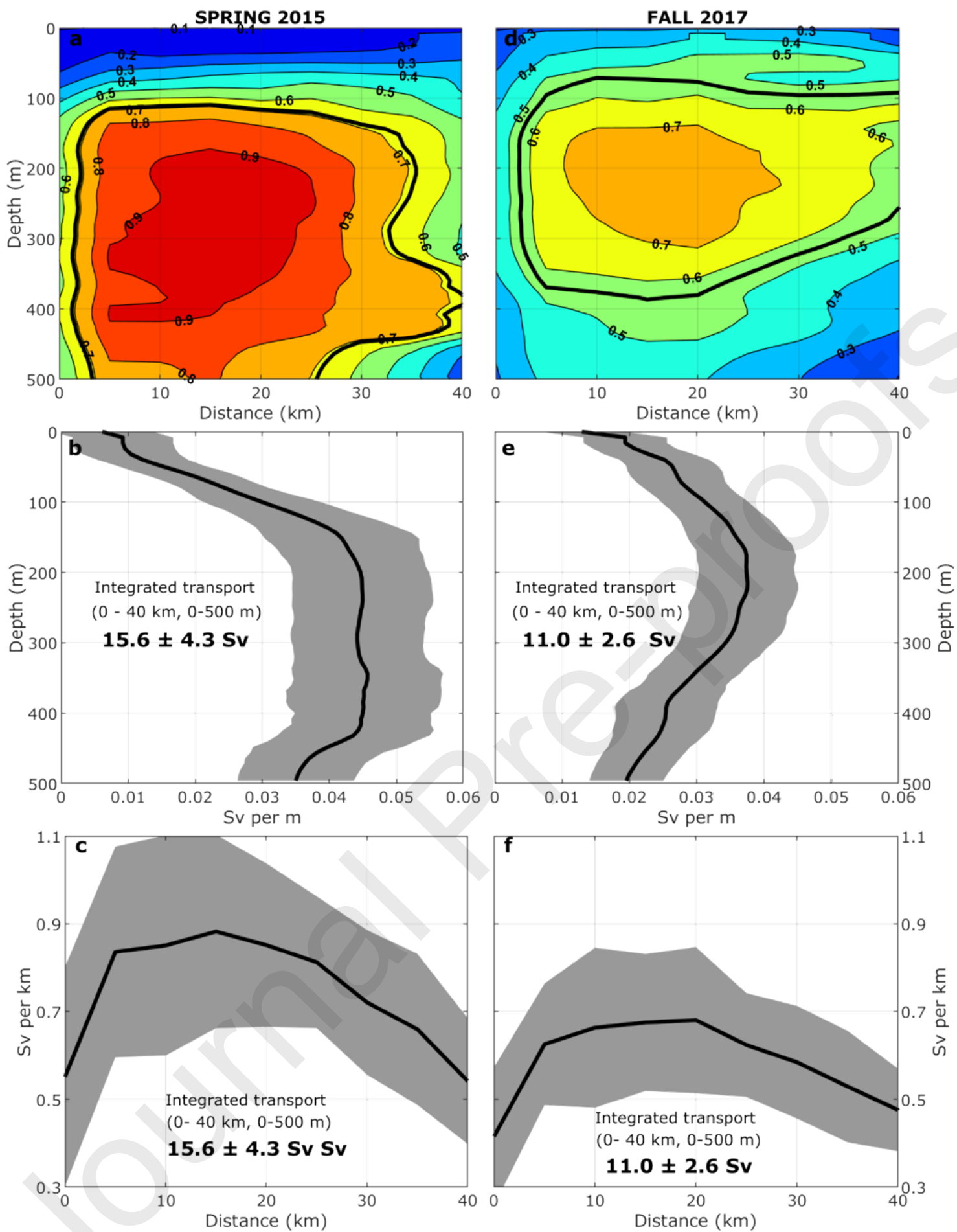

Figure 6. Mean cross-shore sections $\left(9^{\circ} \mathrm{S}-6^{\circ} \mathrm{S}\right)$ of the alongshore velocity component and integrated transports. (a, d) Mean cross-shore section of alongshore velocity (in $\mathrm{m} \mathrm{s}^{-1}$ ) between the shelf break and $40 \mathrm{~km}$ offshore; the bold black solid line contours the core of the NBUC, i.e., the area where the alongshore velocity is greater than $70 \%$ of its maximum. (b, e) Mean vertical profile of alongshore transport integrated from the shelf break to $40 \mathrm{~km}$ offshore. The average total transport and associated deviation (in bold) were integrated from the shelf break to $40 \mathrm{~km}$ offshore and from the surface to $500 \mathrm{~m}$ depth. (c, f) Mean cross-shore distribution of the alongshore transport integrated between the surface and $500 \mathrm{~m}$ depth. Grey shaded areas correspond to the deviation around the mean. Panels (a), (b) and (c) correspond to spring 2015, while panels (d), (e) and (f) correspond to fall 2017. 


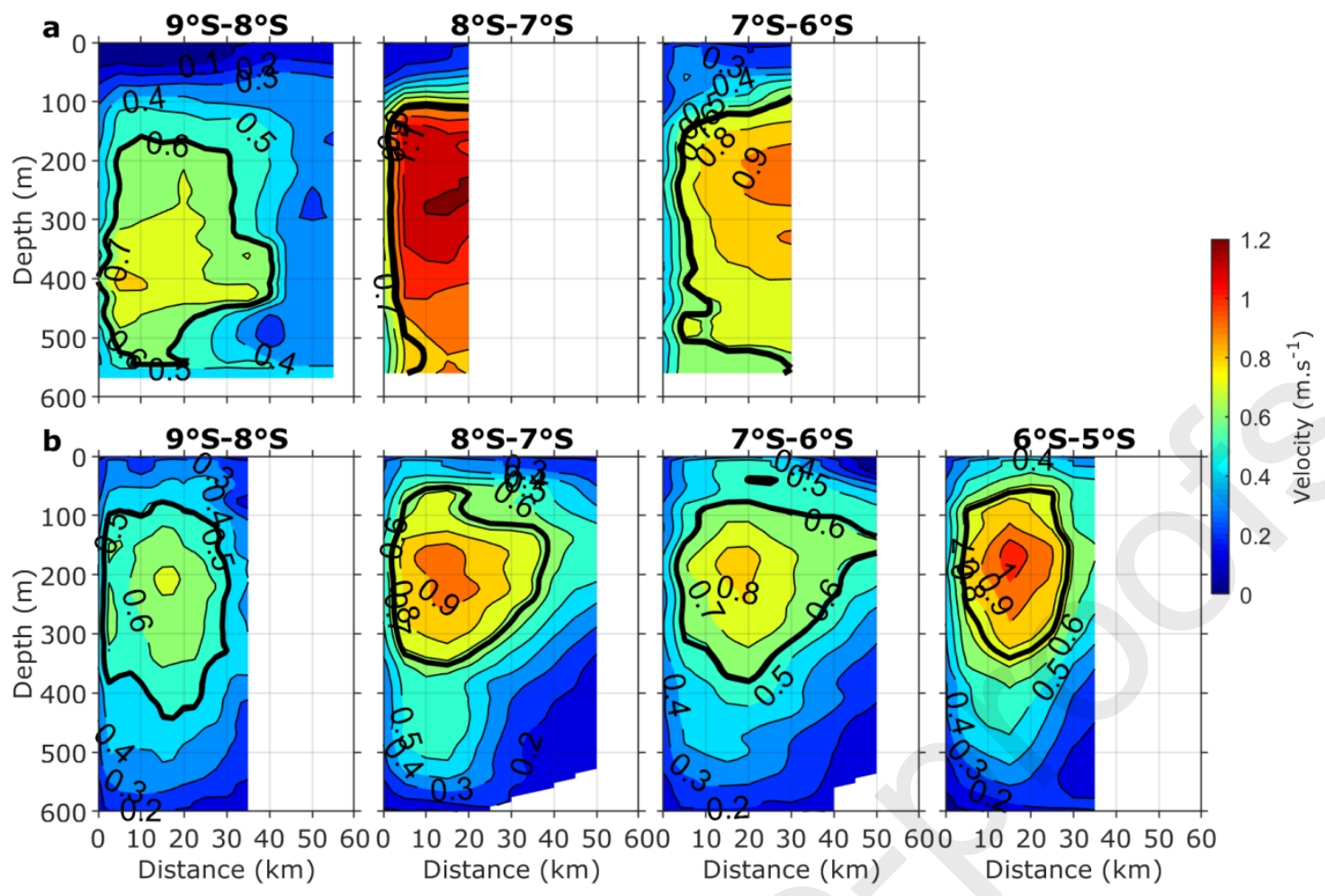

Figure 7. Mean cross-shore sections (from the shelf break) of the alongshore velocity (in $\mathrm{m} \mathrm{s}^{-}$ 1) by latitude bands during spring 2015 (a) and fall 2017 (b). The contour interval is $0.1 \mathrm{~m} \mathrm{~s}^{-1}$. In each panel, the bold black solid line contours the core of the NBUC, i.e., the area where the alongshore velocity is greater than $70 \%$ of its maximum. 


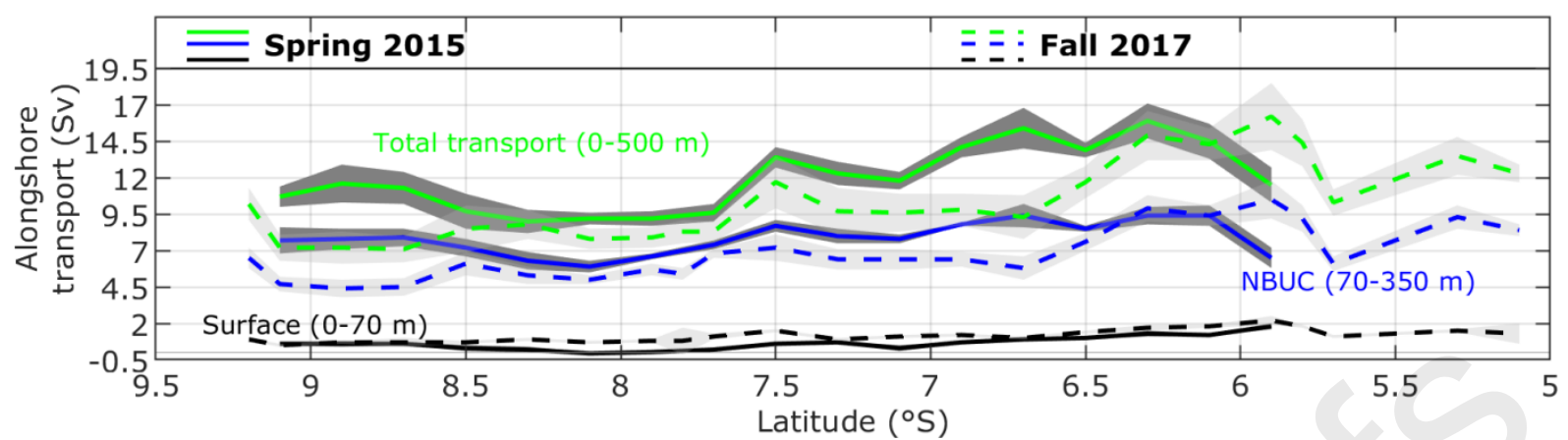

Figure 8. Meridional variation of the alongshore transport (in Sv) integrated between the shelf break and $20 \mathrm{~km}$ offshore for three different layers: 0-70 m (black lines), 70-350 $\mathrm{m}$ (blue lines) and 0-500 m (green lines) depths. Grey shaded areas correspond to the standard deviations around the mean transports. Black, blue and green dots correspond to transport values obtained from previous observations during the same months of ABRAÇOS surveys (see Table 1). 

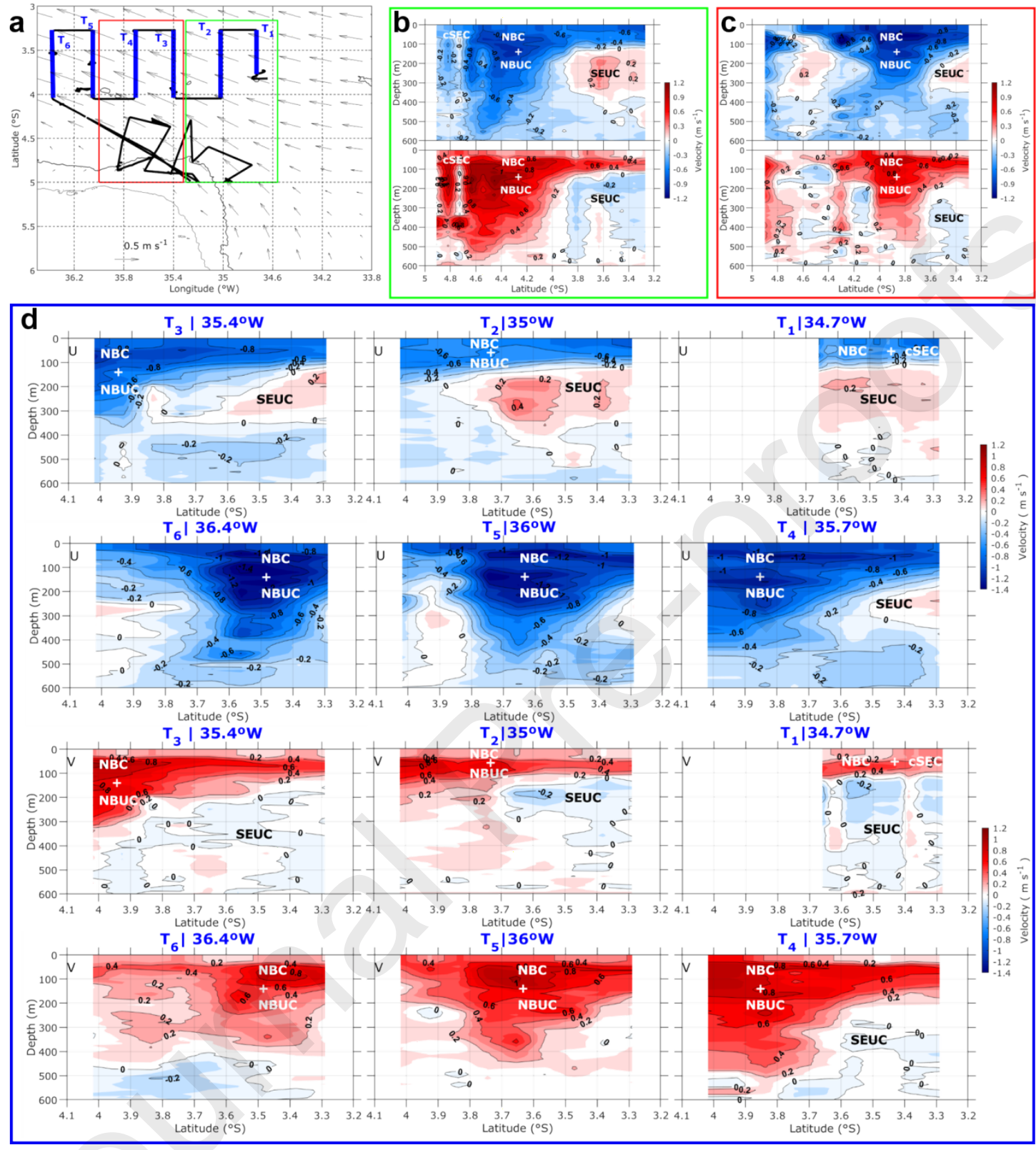

Figure 9. (a) Transect positions superimposed on geostrophic currents. Mean zonal (U; upper panels) and meridional (V; lower panels) currents between: (b) $5^{\circ} \mathrm{S}$ and $3.3^{\circ} \mathrm{S}$ at $\sim 35^{\circ} \mathrm{W}$ (green rectangle in (a)); (c) $5^{\circ} \mathrm{S}$ and $3.3^{\circ} \mathrm{S}$ (red rectangle in (a)); and (d) along six latitudinal transects (T1 to T6) between $34.7^{\circ} \mathrm{W}-36.4^{\circ} \mathrm{W}$ (blue transects in (a)). 

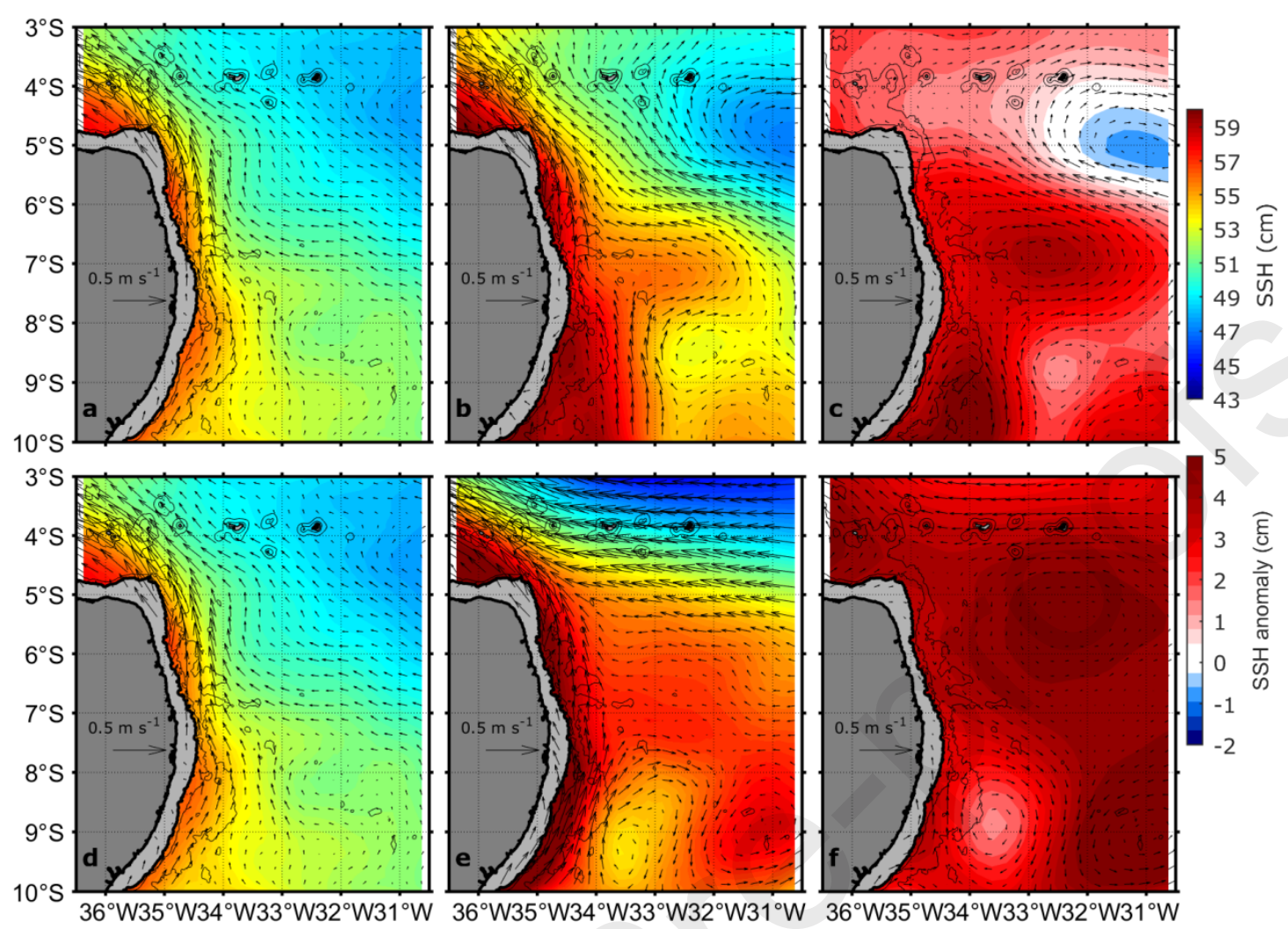

Figure 10. SSH (in cm) superimposed on geostrophic current velocities. Climatologies for (a) spring (Sept. 29 - Oct. 21) and (d) fall (April 08 - May 09) periods, computed with data from January 1993 to December 2018. (b, e) SSH and geostrophic current velocities for spring 2015 and fall 2017 conditions. (c, f) Anomalies in SSH (in cm) and geostrophic current velocities (difference between mean and climatological conditions). The first row ( $a, b, c)$ corresponds to spring, while the second row (d, e, f) corresponds to fall. Shaded grey area correspond to the shelf. The fine black lines represent the isobaths $1000 \mathrm{~m}$ and $3000 \mathrm{~m}$. 

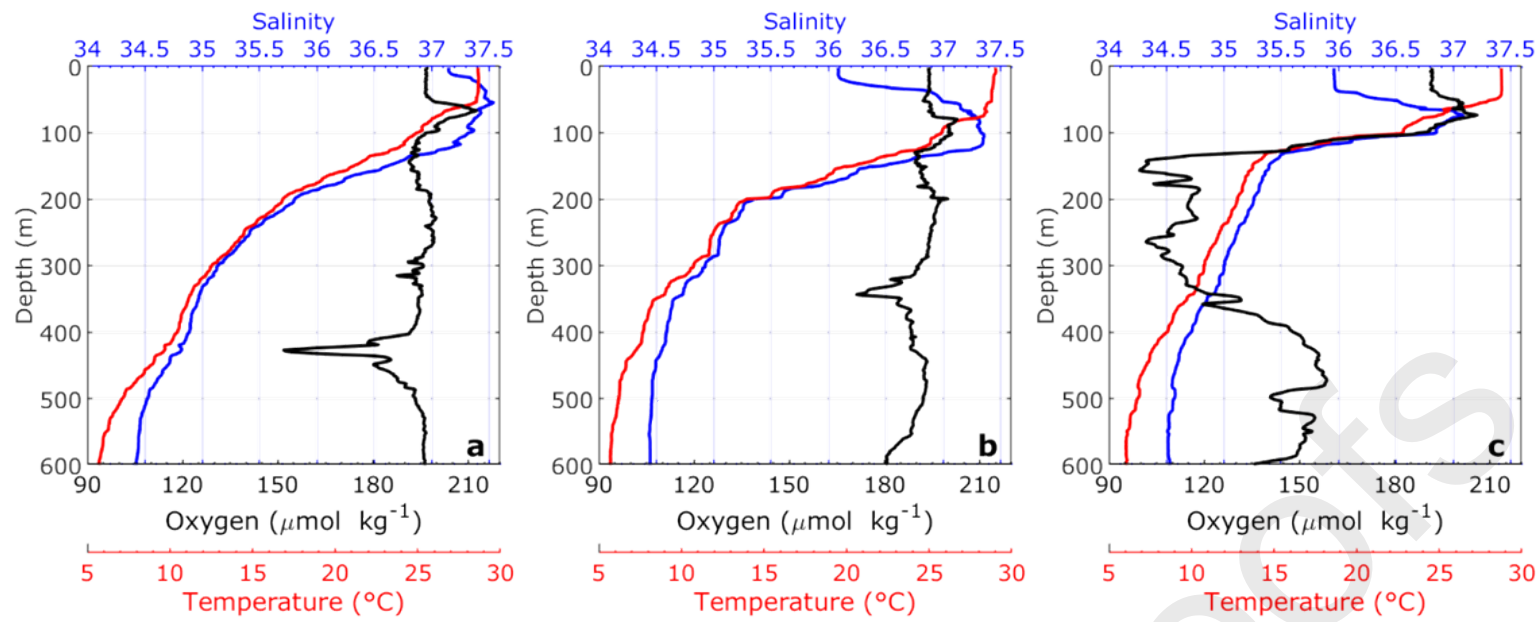

Figure 11. Vertical profiles of temperature (red lines), salinity (blue lines) and oxygen (black lines) at (a) $8.9^{\circ} \mathrm{S}, 34.6^{\circ} \mathrm{W}$; (b) $5^{\circ} \mathrm{S}, 35^{\circ} \mathrm{W}$ and (c) $3.8^{\circ} \mathrm{S}, 35^{\circ} \mathrm{W}$ in fall 2017. 
Re-submission Manuscript PROOCE-D-20-00022

\section{Highlights}

- North Brazil Undercurrent (NBUC) and Current (NBC) are important AMOC pathway

- Using ADCP we finely describe the NBUC-NBC characteristics at two seasons

- We propose a comprehensive picture of NBUC-NBC spatial patterns and transition

- We show how mesoscale activity can impact the surface nearshore circulation 


\section{Declaration of interests}

The authors declare that they have no known competing financial interests or personal relationships that could have appeared to influence the work reported in this paper.

$\square$ The authors declare the following financial interests/personal relationships which may be considered as potential competing interests: 